
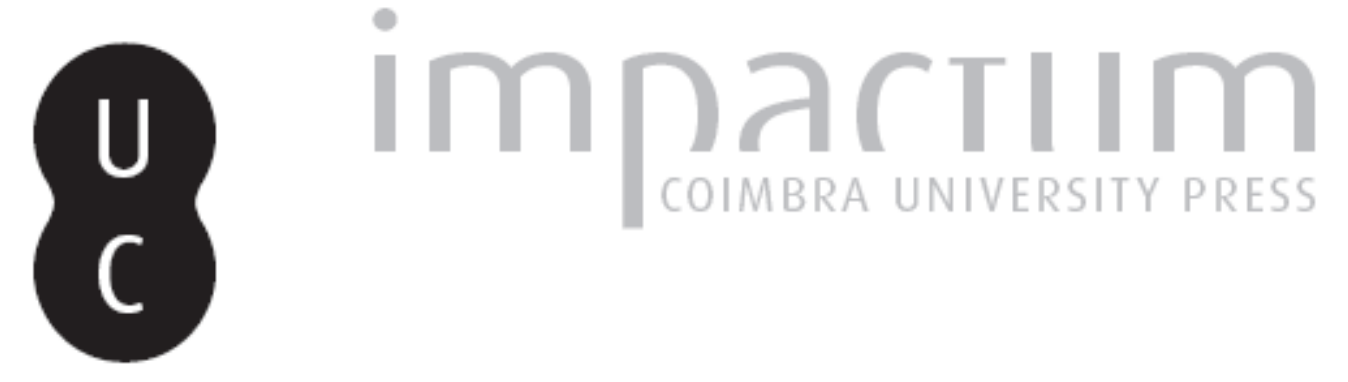

\title{
Global value chain disintegration and the labour market effects of international trade: the lesson of OPT between the EU and the CEECS in the 1990s
}
Autor(es):
Celi, Giuseppe

Publicado por: Faculdade de Direito da Universidade de Coimbra

URL

persistente:

URI:http://hdl.handle.net/10316.2/39883

DOI:

DOI:https://doi.org/10.14195/0870-4260_58_3

Accessed : $\quad$ 26-Apr-2023 12:34:05

A navegação consulta e descarregamento dos títulos inseridos nas Bibliotecas Digitais UC Digitalis, UC Pombalina e UC Impactum, pressupõem a aceitação plena e sem reservas dos Termos e Condições de Uso destas Bibliotecas Digitais, disponíveis em https://digitalis.uc.pt/pt-pt/termos.

Conforme exposto nos referidos Termos e Condições de Uso, o descarregamento de títulos de acesso restrito requer uma licença válida de autorização devendo o utilizador aceder ao(s) documento(s) a partir de um endereço de IP da instituição detentora da supramencionada licença.

Ao utilizador é apenas permitido o descarregamento para uso pessoal, pelo que o emprego do(s) título(s) descarregado(s) para outro fim, designadamente comercial, carece de autorização do respetivo autor ou editor da obra.

Na medida em que todas as obras da UC Digitalis se encontram protegidas pelo Código do Direito de Autor e Direitos Conexos e demais legislação aplicável, toda a cópia, parcial ou total, deste documento, nos casos em que é legalmente admitida, deverá conter ou fazer-se acompanhar por este aviso.

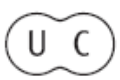




\section{UNIVERSIDADE DE COIMBRA \\ FACULDADE DE DIREITO}

\section{BOLETIMDECCÊNCIASECONÓNICAS}

VOLUME LVIII

$\begin{array}{llll}2 & 0 & 1 & 5\end{array}$

COIMBRA 


\section{GLOBAL VALUE CHAIN DISINTEGRATION AND THE \\ LABOUR MARKET EFFECTS OF INTERNATIONAL TRADE}

\section{THE LESSON OF OPT BETWEEN THE EU AND THE CEECs IN THE 1990s}

\section{Introduction}

In recent years the dynamics of world economy has been epitomized by three novel developments that have been perceived as producing significant effects on labour markets of advanced countries: i) the opening up to market economy of China, India and (ex-communist) Central and Eastern European countries (CEECs), a shift that has doubled the world's labour force (the "Great Doubling", according to the words of FREEMAN, 2007); ii) the spreading out of information and communication technologies that have hugely facilitated international fragmentation of production and outsourcing of services; iii) the growth of migration flows from developing countries. All these dramatic changes in the processes of 
international economic integration have contributed to the increase of insecurity among workers of advanced economies both in terms of fear of losing jobs and also in terms of expected decline in remunerations.

Although these feelings of anxiety over globalization are currently supported by anecdotal evidence, polling data and studies based on individual-level survey data, until recent years the majority of academic opinion did not believe that the growing integration between advanced countries and emerging economies was producing an adverse impact on labour markets of developed countries. In effect, the traditional theory of international trade based on comparative advantage stands for a good parable about the benign effects of globalization as it affirms that differences in technology or factor endowment across countries are sources of mutual gains when economies trade with each other.

However, the standard textbook model of international trade - the two-good, two-factor Heckscher-Ohlin-Samuelson (HOS) model - also makes clear that although free trade increases aggregate welfare, it determines a redistribution of real income between factors of production. For this reason the HOS model has been assumed as the starting point to interpret stylized facts concerning trade, wages and jobs in the eighties of the last century. In effect, at the beginning of 1990s the debate on the link between international trade and labour markets of advanced countries gathered momentum and attained growing importance among economists in order to shed light on developments occurring in the previous decade. Two pieces of empirical evidence have awakened new interest in the labour market effects of international trade. On the one hand, income distribution has changed greatly in the U.S., with a widening gap between the wages of skilled and 
unskilled workers. Although West European countries have not shown such a dramatic change in income differentials (with the exception of the UK), they have exhibited high rates of unemployment, especially among less skilled workers. On the other hand, during the same period, a growing penetration of emerging economies' exports into advanced economies' markets was taking place (the aggressive dynamism of the socalled "Asian Tigers" or "Asian Dragons").

It seemed quite natural to associate these stylized facts in terms of causality nexus in the presence of a standard theory of international trade (HOS model) which makes strong predictions about the distributive effects of international trade: take the two factors as skilled and unskilled labour, suppose that the rapidly growing developing countries are abundant in unskilled labour, and the model predicts that growth of trade between developed and developing countries will in developed countries shift production towards skill-intensive products, drive down the relative price of unskilled-intensive goods, raise the real wages of skilled workers and reduce the real wages of the unskilled. Add a story about downward rigidity of the real wages of the unskilled in socially-regulated labour markets and the model will generate unemployment rather than relative wage changes.

Faced with two striking empirical phenomena and a theory which links the two, there was an almost overwhelming temptation to see the empirical phenomena as confirming the theory. However, when all implications deriving from the chain of causation postulated by HOS model were compared with empirical evidence some crucial inconsistencies emerged. In effect, at the beginning of the 1990s studies investigating the link between trade and labour market carried out a simple evaluation of consistency between data and standard 
theory of international trade (HOS model and StolperSamuelson theorem). A particularly striking contribution to the debate was Lawrence and Slaughter's comparison of the predictions of the Stolper-Samuelson analysis with the facts of industrial adjustment in the United States in the 1980s (Lawrence and Slaughter, 1993). The theoretical story has three steps: (1) growing exports of unskilledintensive products by developing countries drives down the price of these products in developed countries, thereby (2) driving down the relative wage of unskilled labour, causing substitution in production towards unskilled labour, and (3) maintaining full employment by inter-sectoral substitution of production towards more skill-intensive products. LAWRENCE and Slaughter, proxying the skilled/unskilled distinction by nonproduction/production workers, (1) found no evidence of relative price changes, (2) they demonstrated (at three different levels of aggregation) that the rise in the relative wages of non-production workers was accompanied by an increase in the relative employment of non-production workers in almost all sectors, and (3) they found no evidence of an inter-sectoral shift in production. The evidence they presented was strongly suggestive of a chain of causation that runs from an exogenous increase in the demand for skilled workers in most sectors (arising from technological change) driving up the relative wage of such workers rather than the chain of causation in the Stolper-Samuelson story.

The Lawrence and Slaughter conclusion of a weak (or even inexistent) link between trade and labour market was supported by other contributions, like KRUGMAN and Lawrence (1994), Krugman (1994), and, in less degree, Sachs and SHATZ (1994). Almost until the end of the 1990s, the great bulk of academic opinion was opposed to the view that there 
is a strong link between the growth of trade and the growth of labour market inequality. FREEMAN (1995), surveying the differing positions taken, noted the paradoxical fact that trade theorists are in the forefront of those denying the importance of trade in income distribution.

Incidentally, WoOD (1994) and LEAMER (1995) are unusual among trade economists in finding evidence of strong links between trade and labour markets. In particular WoOD following a factor content of trade (FCT) approach modified in order to take account of North-South differences in inputoutput matrices - calculated the impact of North-South trade on unskilled labour demand in developed countries and he observed that the shedding of jobs was twice the amount estimated in previous studies. The important point raised by Wood was that the previous studies didn't consider that the South exports to the North are non competing; in other words, the goods exported by developing countries are different from North products, even if they belong to the same statistical class. By using the factorial coefficients matrix of developed countries as estimator, the previous FCT studies have underestimated the unskilled labour content of South exports to the North and consequently they have undervalued the displacement effect of North-South trade on unskilled labour demand in developed countries. Hence Wood warned against the risk of understating the effects of trade on labour markets if product heterogeneity is not considered adequately.

Another way to take due account of heterogeneity in trade and, consequently to recover the relevance of labour market effects of international trade, is to consider vertical product differentiation (differentiation by quality) in trade flows. CELI and Smith (1999) and Celi and Segnana (2000) provided a 
treatment of the labour market effects of international trade, based on a model in which vertical intra-industry trade is explained on Heckscher-Ohlin principles. The model is more consistent with stylised facts about North-South trade than the traditional Heckscher-Ohlin model of inter-industry trade. Applying the model to trade between Italy and non advanced countries and inferring the factor content of intraindustry trade from the inter-sectoral relationship between factor intensity and average unit values of exports, they found that the labour market effects of intra-industry trade added significantly to the estimated factor market impact of trade.

The contributions of the 1990s that found a significant impact of trade on labour markets in advanced countries represented the minority view in the debate on trade and jobs. As mentioned above, the weight of academic opinion denied the relevance of international trade in determining the unskilled-adverse shift in labour demand in developed countries and, on the contrary, emphasized the significant role played by skill-biased technological change.

However, it is quite paradoxical that the idea that the labour market effects of globalization were irrelevant was prevailing in a decade, the 1990s, in which the formation of North-South value chains represented the crucial passage from the "old paradigm" to the "new paradigm" of globalization, according to the words of BALDWIN (2006, 2011). As reported by BALDwIN (2013), two simple indicators testify this dramatic change: 1) the G7 share of world income; 2) the G7 share of world export ${ }^{1}$. The first one moved from the maximum value of $67 \%$ in 1989 to less than $50 \%$ in 2010 (the same value of 1900!); the second one shifted from the maximum value

\footnotetext{
${ }^{1} \mathrm{G} 7$ is a group consisting of seven advanced economies: Canada, France, Germany, Italy, Japan, UK and United States.
} 
of $52 \%$ in 1991 to $46 \%$ in 2001 (the same value of 1948) and then collapsed to $23 \%$ in 2010 (half the post-war figure!). If we restrict our attention to manufacturing output, the $G 7$ share of world manufacturing changed from 65\% in 1990 to $47 \%$ in 2010 . In the same period, a group of other seven countries - China, Korea, India, Indonesia, Thailand, Turkey and Poland - saw its share rise from $7 \%$ to $22 \%$, a growth that almost offsets the decline of the G7 share. Significantly, as remarked by BALDWIN (2013), all these countries (with the exception of India) are inserted into global value chains of United States, Germany (particularly Poland and Turkey) and Japan (especially China, Korea, Indonesia and Thailand).

Since the 1990s, the flourishing of North-South global value chains has profoundly changed global economic interactions and, in virtue of this transformation, the dynamics of world trade composition has been increasingly affected by flows deriving from international fragmentation of production.

Although in the debate on trade and jobs the idea of the irrelevance of labour market effects of globalization continued to prevail among most economists, in the second half of the 1990s Feenstra and Hanson (1996) and Feenstra (1998) made clear that the impact of trade on labour markets could be substantial if vertical trade was considered: in this case, "vertical trade" was not referred to quality product differentiation (as in Celi and Smith, 1999) but to trade flows deriving from the interchange between intermediates and final goods or, in other words, from international fragmentation of production.

In the first decade of 2000, it was inevitable that the debate on the labour market effects of globalization shifted from the role of trade to that of outsourcing ${ }^{2}$.

${ }^{2}$ Over the past decade, the literature on the impact of out- 
The objective of this paper is to investigate the implications for labour markets of the process of trade liberalization involving EU countries and Central and Eastern European countries (CEECs) in the 1990s, by an approach addressed to study vertical forms of integration in EU-CEECs trade. In particular, outward processing traffic (OPT) is explored. OPT is a type of vertical disintegration in international trade which during the 1990 s became a main channel of interdependence between EU countries and Central Eastern European countries (CoRAdo 1994). During that decade, OPT statistics - provided by Comext Eurostat database - turned out to be a quite reliable instrument to capture the dynamics of international fragmentation in EUCEEC trade for the reason that at that time liberalization between EU and CEECs was not complete and OPT benefited from a preferential trade regime in the EU with respect to trade in final goods; hence, a significant part of OPT flows were officially declared and recorded.

Therefore, the focus on OPT between EU and CEECs during the 1990s offers the opportunity to experiment a better assessment of the impact of trade on labour markets in a decade in which, as mentioned above, the majority of academic opinion rejected the labour market effects of globalization. The paper is a factor content of trade (FCT) study in the tradition of Wood (1994), where due consideration is given

sourcing/offshoring on labour markets (in advanced but also in developing countries) has become very copious. Among the most significant empirical contributions exploring the impact of outsourcing on labour markets of advanced countries, it is worth mentioning: Amiti and Wei (2005, 2009); Ando and Kimura (2007); Egger and Egger (2005); Ekholm and Hakkala (2006); Helg and Tajoli (2005); Hertveldt and Michel (2012), HsieH and Woo (2005); Geishecker (2006); Lorentowicz et al. (2005). 
to heterogeneity in trade, and it builds on CELI and SMITH (1999), where the role of quality differentiation in trade is emphasized in order to capture substantial effects of trade on labour markets. Here, with respect to CELI and SMITH (1999), heterogeneity in trade matters too, but not only in terms of the quality of final goods but also in terms of the fragmentation of productive processes. As remarked by Feenstra (1998), trade flows deriving from the vertical disintegration of production on an international scale could have the same within-industry effects as technology on the displacement of demand for unskilled workers in developed countries. But usually economists assume that international trade has an impact on labour markets via between-industry adjustments, ignoring the complementarities between trade and technology that are so evident in the recent dynamics of vertical disintegration arising in advanced countries.

This paper introduces the dimension of vertical disintegration in the treatment of the labour market effects of international trade. Specifically, it evaluates the differential impact of OPT flows with respect to final flows on the labour markets of EU countries. Two EU countries are investigated, Germany and Italy, because of their importance in total EUCEEC OPT flows and because they embody two different models of outsourcing towards the CEECs. The factor content of trade analysis conducted both at inter-industry trade and intra-industry trade level shows a more significant impact of OPT flows than final flows. In particular, results suggest that the labour market effects of intra-industry trade flows deriving from the vertical disintegration of production add significantly to the estimated factor market impact of trade.

The paper is structured in five sections. Section 2 provides a short discussion of EU trade policy in textile and clothing, 
focussing on the preferential regime granted to OPT in the 1990s. Section 3 offers a short overview of OPT in the EU during the 1990s from which it is possible to extrapolate the reasons to focus the analysis on EU-CEECs trade. Section 4 provides an empirical application to test the differential impact of OPT flows with respect to final flows. The final section contains some concluding remarks.

\section{The EU Trade Policy in Textile-Clothing and the OPT System in the 1990s}

Outward Processing Traffic (OPT) refers to trade flows associated with a particular form of sub-contracting carried out by EU firms on an international scale. The sub-contracting agreement involves an EU contractor who temporarily exports a commodity to be processed abroad by a sub-contractor and then re-imported. The contract provides that the ownership rights over the input supplied are retained by the contractor who is committed to collect his output after processing; the contractor also retains the right to market the final product or to process the reimported product further as necessary ${ }^{3}$.

In comparison with a mere sub-contracting agreement, OPT benefits from a preferential trade regime in the $\mathrm{EU}^{4}$. On this regard we have to distinguish fiscal OPT from eco-

${ }^{3}$ In addition, the contractor maintains the right to carry out quality control and to reject the sub-contractor output on the basis of quality, timing of delivery and other contractual conditions.

${ }^{4}$ For legal aspects of the OPT arrangement see PeLLEgrin (1995). 
nomic OPT $T^{5}$. The first term refers to EC customs regulation $2473 / 86$ which establishes that duties are paid only on the added value of re-imported goods. Firms using fiscal OPT must apply for specific authorisations and declare re-imports as OPT. Since 1993, under Europe Agreements ${ }^{6}$, tariffs on OPT flows in textile and clothing have been suppressed totally, while normal reimports under Multi-fiber Arrangement (MFA) quotas continued to be regulated by current tariffs. The second term refers to a specific regime to clothing (as established by EC regulation 636/82) according to which OPT requires the use of fabrics of EC origin. For East European countries, duties at the $0 \%$ rate are granted on re-importation,

${ }^{5}$ Cfr. Scheffer (1994).

${ }^{6}$ The Europe Agreements have been anticipated by so-called Interim Agreements, signed in the years 1992 (Czech Republic, Hungary, Poland and Slovakia), 1993 (Bulgaria and Romania), 1995 (Estonia, Latvia, and Lithuania), and 1997 (Slovenia). The aim of the Interim Agreements was similar to that of the Europe Agreements: reducing trade barriers among the EU15 and the CEECs. At the beginning of the 1990s several studies attempted to predict the future evolution of EU's trade with Central Eastern European countries and its impact on European welfare (CoLLINs and Rodrick, 1991; Wang and Winters, 1992; Hamilton, Winters, Hughes and Smith, 1992; Baldwin, 1994). However, at that time, a clear definition of the pattern of trade of the CEE economies was not emerging - because of the ongoing process of transition in these countries- and consequently the estimates of the impact of trade were uncertain. Also the authors using general equilibrium models to estimate the effect of EU-CEEC trade on EU economies complained about a lack of strong results due to the models' inability to capture intra-sectoral adjustments (GASIOREK, SMITH and Venables, 1994). More recent assessments of Europe Agreements' impact on European welfare have produced more significant (and positive) results (see, inter alia, EGGER and LARCH, 2011). 
after OPT, of certain products listed in the Annex of EC Regulation 636/82. The 1982 regulations established an ad hoc regime for OPT under which specific OPT quotas were reserved to producers carrying out outward processing, while before 1982 OPT flows were regulated by Multi-fiber Arrangement for global textile and clothing. On 1 January 1993 , the European single market has replaced the national quota with a single "Community" quota".

The intent of the regulations was to defend textile-clothing industry employment in the EU while by offering a means by which the industry can adapt to competition from direct imports (SCHEFFER, 1994). Although OPT of textile and clothing from the EU to CEECs boomed after 1990, the phenomenon is not new. Almost 30 years ago, long before the crash of COMECON, German producers especially started to implement outward processing in Yugoslavia, Poland and other Central Eastern European countries (Frobel, HeINRICHS and KREYE, 1980) ${ }^{8}$. OPT was the reaction of the clothing industry to the sharp increase of imports from low cost countries in spite of the protection provided by Multi-Fibre Arrangement (MFA). These developments in the restructuring of textile-clothing industry in the EU have gone with the change in the institutional framework of protection provided by EU trade policy in the form of a quicker relaxation of OPT quotas than non-OPT quotas.

Since 1974, import penetration in developed countries'

${ }^{7}$ Cfr. Graziani (2001).

${ }^{8}$ Thanks to tariff provisions similar to the European OPT system, also US producers started in the sixties to use outward processing. Under the US 9802 Special Tariff System, in recent years US textile and clothing outward processing trade with Mexico and the Caribbean countries has boomed (cfr. Graziani, 2001). 
markets has been regulated by MFA. Under this agreement, quantitative restrictions on imports into developed countries were negotiated on a bilateral basis. The quota system authorized the amount of imports on which specific tariffs of each importing country were applied, with provisions for annual increase in the quotas that differ across importing countries. In the case of EU countries, before the completion of the single European market, quotas were allocated to countries by the European Commission on the basis of previous trading patterns 9 . In doing so, the Commission aimed to prevent market disruption and to encourage freer trade among new entrants ${ }^{10}$. Despite its pervasive protection, MFA failed to prevent the dramatic increase of extra-EU imports. According to STEELE (1995), the same completion of single Market - with the abandonment of the EU's quota allocation system and with the introduction of a single Community quota in 1993 - could have contributed to rising textile and clothing imports from extra-EU countries through the "emergence of distributors able to operate on a pan-European scale... and to place very large orders, thus taking full advantage of low cost sources of supply outside the EU'. GiNZBURG and SimONAZZI (1995) also have noted a strict correlation between a member state's propensity to import and the organization of its clothing distribution structure:

“...Where the distributive sector was too weak in comparison with the power of distribution, like in the UK, the struggle resulted in early and intense relocation of production linked to outsourcing in the low-cost countries of the Far East. Where the distributive sector was weaker (less concentrated)

${ }^{9}$ Cfr. Steele (1995).

${ }^{10}$ For example, when Spain and Portugal joined the EU in 1986, they were allocated very small shares of Community-wide quotas in line with their former trading patterns. Cfr. STEELE (1995). 
and the manufacturing system was relatively strong two radically different strategies emerged. The high cost firms in Germany relied on international subcontracting of the more labour-intensive stages of production, in the neighbouring Mediterranean and East-European countries. Italian firms pursued a strategy of quality up-grading based on a process of national subcontracting" 1 .

So, in the nineties, the increasing recourse to OPT and the preferential trade regime supporting this practice in the EU could be interpreted as a defensive response of EU textile and clothing firms to the growing competition of extra-EU low cost countries. The Europe Agreements were in line with this strategy. For trade in textile and clothing, they established a liberalisation at twice the rate of the multilateral liberalisation negotiated in the Uruguay Round ${ }^{12}$. Furthermore, the Europe Agreements aimed to "construct a vertically integrated international sector encompassing high value-added phases located domestically as well as low-cost sourced operations abroad" (GinZBurg and SimonAZZI, 1995, p. 9). The protocols concerning textile and clothing involved the following terms: an increase in the volumes of quotas and their rates of growth, the total suppression of certain quotas (with timing linked to the MFA), the removal of customs duties on OPT, the removal of tariffs on direct imports of six years ${ }^{13}$.

So the elimination of EU tariffs on OPT imports from the CEECs might explain the boom of OPT flows between

${ }^{11}$ However, in the 1990s Italy has increased its recourse to OPT. The rising relocation of Italian garment production has been acknowledged by the Italian government. In fact, restrictions on outward processing have been relaxed from $15 \%$ of total output to 30\% (cfr. RiCCHETTI, 1993).

${ }^{12}$ Cfr. Sмith (1994).

${ }^{13}$ See Lewis (1995), p. 62, and Winters (1992). 
the EU countries and the CEECs in the nineties. However, OPT as a tariff system may become less important after 1998 with the transition to a trade regime in which tariff barriers on non-OPT flows are removed also. After 1998, OPT regulations no longer require production of fabrics in EU countries; so EU firms can freely import garments incorporating fabric made in the CEECs (Graziani, 2001).

\section{An Overview of OPT Flows in EU Countries}

The statistical regime instituted in order to monitor OPT allows one to observe the international disintegration of production in EU during the nineties. The fact that OPT has to be declared to the custom authorities allows Eurostat to process data distinguishing different statistical regimes: 1) exports for and imports after outward processing, 2) exports after and imports for inward processing, 3) normal exports and imports ${ }^{14}$. The Eurostat-Comext dataset provides information on OPT flows and final trade flows at a very high level of product disaggregation since 1988 for each EU reporting country. Although OPT data describes only a part of the vertical disintegration of production at the international level, it can offer a useful preliminary description of this phenomenon.

Table 1 reports a comparison between OPT flows and final flows with reference to Extra-EU trade of EU countries during the 1990's. Although the OPT flows represented a small fraction of final flows, they grew at a faster pace. From

${ }^{14}$ With regard to OPT flows, in the present context we are interested in flows at point 1 , because the analysis focuses on the relocation of the production segments from EU countries to the CEECs. 
1989 to 1997 the OPT flows of the whole EU area increased more than $160 \%$, whereas final flows rose by $63 \%$. Only in three countries (Netherlands, Spain and Portugal) was the rate of growth of final flows higher than that of OPT flows. So, on the whole, OPT data from EU countries confirm the increasing importance of vertical flows in world trade as reported in several studies published in the $1990 \mathrm{~s}^{15}$.

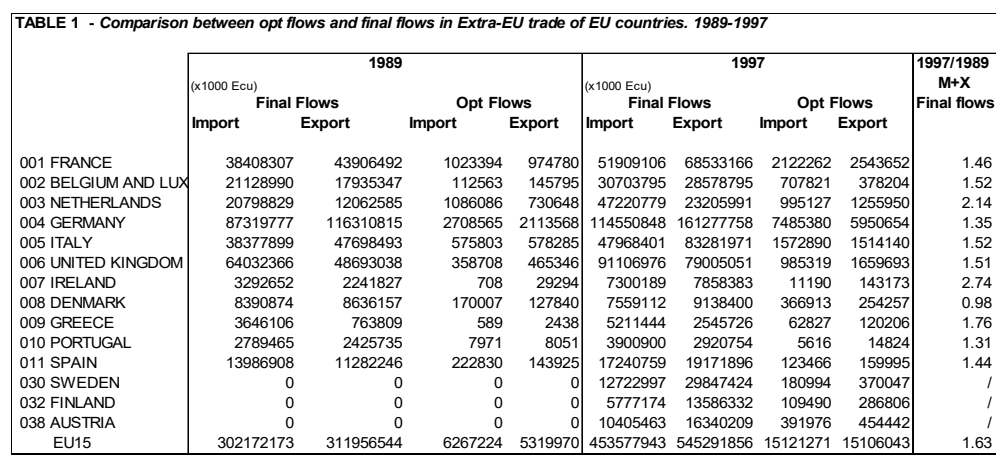

Source: Comext

Table 2 shows that in 1989 the main users of OPT were five countries: Germany, France, the Netherlands, Italy and the UK. The first one accounted for more than $40 \%$ of total EU OPT flows, France and the Netherlands followed with shares of more than $17 \%$ and $15 \%$ respectively, then Italy and the UK with shares below 10\%. In 1997 the rank of main users changed because of the sharp drop in the Netherlands' OPT: now only Germany, France and Italy display shares higher than $10 \%$.

15 See Hummels, Rapoport, Kei-Mu Yi (1998), Feenstra (1998), inter alia. 


\begin{tabular}{|c|c|c|c|c|}
\hline \multirow[b]{3}{*}{001 FRANCE } & \multicolumn{2}{|c|}{$\begin{array}{l}\text { Imports+Exports (Extra-EU) } \\
\text { millions of ECU }\end{array}$} & \multicolumn{2}{|c|}{ OPT Shares } \\
\hline & 1989 & 1997 & 1989 & 1997 \\
\hline & 1,998 & 4,666 & $17.24 \%$ & $15.44 \%$ \\
\hline 002 BELGIUM AND LUX & 258 & 1,086 & $2.23 \%$ & $3.59 \%$ \\
\hline 003 NETHERLANDS & 1,817 & 2,251 & $15.68 \%$ & $7.45 \%$ \\
\hline 004 GERMANY & 4,822 & 13,436 & $41.62 \%$ & $44.45 \%$ \\
\hline 005 ITALY & 1,154 & 3,087 & $9.96 \%$ & $10.21 \%$ \\
\hline 006 UNITED KINGDOM & 824 & 2,645 & $7.11 \%$ & $8.75 \%$ \\
\hline 007 IRELAND & 30 & 154 & $0.26 \%$ & $0.51 \%$ \\
\hline 008 DENMARK & 298 & 621 & $2.57 \%$ & $2.05 \%$ \\
\hline 009 GREECE & 3 & 183 & $0.03 \%$ & $0.61 \%$ \\
\hline 010 PORTUGAL & 16 & 20 & $0.14 \%$ & $0.07 \%$ \\
\hline 011 SPAIN & 367 & 283 & $3.17 \%$ & $0.94 \%$ \\
\hline 030 SWEDEN & 0 & 551 & $0.00 \%$ & $1.82 \%$ \\
\hline 032 FINLAND & 0 & 396 & $0.00 \%$ & $1.31 \%$ \\
\hline 038 AUSTRIA & 0 & 846 & $0.00 \%$ & $2.80 \%$ \\
\hline EU15 & 11,587 & 30,227 & $100.00 \%$ & $100.00 \%$ \\
\hline
\end{tabular}

Source: Comext

When the sectoral composition of OPT flows is considered, we can observe that only three main aggregates accounted for more than $80 \%$ of total manufacturing industry flows: Machinery (electrical and non electrical, CN 84 and 85), Textiles-apparel (CN 50-63) and Transport (CN 86-89).

In particular, the first column of table 3 shows that in 1989 Machinery accounted for more than 40\% of OPT between EU and Extra-EU countries, while Textile-apparel and Transport accounted for 33\% and 7\% respectively. In 1997 the weight of the Textile-apparel sector increased further. Interestingly, this sectoral concentration of OPT flows links up with a geographical specialisation, indicating a straightforward international division of labour. 


\begin{tabular}{|c|c|c|c|c|c|c|c|}
\hline \multicolumn{8}{|c|}{ Percentage shares } \\
\hline & \multicolumn{7}{|c|}{1989} \\
\hline & Extra-EU & \multicolumn{6}{|c|}{$\begin{array}{ll} & \text { Areas } \\
& \\
& \end{array}$} \\
\hline \multicolumn{8}{|l|}{ Sectors ${ }^{*}$} \\
\hline Text-appar & $33 \%$ & $29 \%$ & $9 \%$ & $62 \%$ & $0 \%$ & $0 \%$ & $100 \%$ \\
\hline Mec-Elect & $41 \%$ & $2 \%$ & $44 \%$ & $3 \%$ & $46 \%$ & $5 \%$ & $100 \%$ \\
\hline Transport & $7 \%$ & $3 \%$ & $1 \%$ & $14 \%$ & $82 \%$ & $0 \%$ & $100 \%$ \\
\hline Others & $19 \%$ & $11 \%$ & $8 \%$ & $41 \%$ & $38 \%$ & $1 \%$ & $100 \%$ \\
\hline \multirow[t]{4}{*}{ Total Manuf } & $100 \%$ & $11 \%$ & $26 \%$ & $26 \%$ & $34 \%$ & $3 \%$ & $100 \%$ \\
\hline & \multicolumn{6}{|c|}{1997} & \\
\hline & \multirow[b]{2}{*}{ Extra-EU } & \multicolumn{5}{|c|}{ Areas } & \\
\hline & & Africa & Asia $^{* *}$ & $\mathrm{CEEC}^{\star \star *}$ & North Ame & South Ame $e^{\star *}$ & Tot Areas \\
\hline \multicolumn{8}{|l|}{ Sectors $^{*}$} \\
\hline Text-appar & $37 \%$ & $12 \%$ & $6 \%$ & $82 \%$ & $0 \%$ & $0 \%$ & $100 \%$ \\
\hline Mec-Elect & $38 \%$ & $2 \%$ & $52 \%$ & $21 \%$ & $23 \%$ & $2 \%$ & $100 \%$ \\
\hline Transport & $9 \%$ & $2 \%$ & $1 \%$ & $8 \%$ & $88 \%$ & $1 \%$ & $100 \%$ \\
\hline Others & $16 \%$ & $5 \%$ & $10 \%$ & $53 \%$ & $30 \%$ & $1 \%$ & $100 \%$ \\
\hline Total Manuf & $100 \%$ & $6 \%$ & $25 \%$ & $46 \%$ & $22 \%$ & $1 \%$ & $100 \%$ \\
\hline
\end{tabular}

$\left(^{\star}\right)$ Text-appar: 50-63; Mec-Elect: 84-85; Transport: 86-89; Total manuf: 28-99 $\left({ }^{\star \star}\right)$ Selected countries

Source: Comext

In particular, table 3 shows that OPT flows in the Textile-apparel sector were almost entirely channelled to the CEECs, Transport OPT flows were mostly directed to North America and OPT flows in machinery were concentrated (to a lesser extent) in Far Eastern countries. Globally, in the 1990s the CEEC area were becoming the main pole of attraction of EU OPT flows, accounting for 50\% of total OPT. This tendency to a sectoral/geographical polarisation of OPT flows is even more evident when we look at a single EU country. For example, in the case of Germany and Italy in 1997 a great part of their total OPT flows (60\% and $70 \%$ respectively) was concentrated on the CEEC area and in the Textile-apparel sector, while in the case of France and the Netherlands OPT flows were mostly oriented towards Far East Asian countries in the Machinery sector (see country tables in annex).

This evident correlation between geographical and sectoral specialisation in OPT flows testifies not only to a strong international division of labour based on comparative advan- 
tages but also to links between countries due to the spheres of influence factors ${ }^{16}$.

However, when we look at the relevance of OPT flows in comparison with the final trade flows at the sectoral and geographical level we can note that only in the case of the CEECs area and in the Textile-apparel sector is the weight of OPT remarkable. Table 4 reports the ratio of OPT flows to final trade flows and shows that only in the case of the CEECs in Textile-apparel is the ratio bigger than one.

For this reason, the next section tries to evaluate the differential labour market impact of OPT flows with respect to the final flows by looking at the CEECs in the textile-apparel sector. Given that Germany and Italy assembled the main part of EU OPT in CEECs in Textile-apparel (60\% and 15\% respectively), the trade impact will be measured with reference to the labour markets of these two countries.

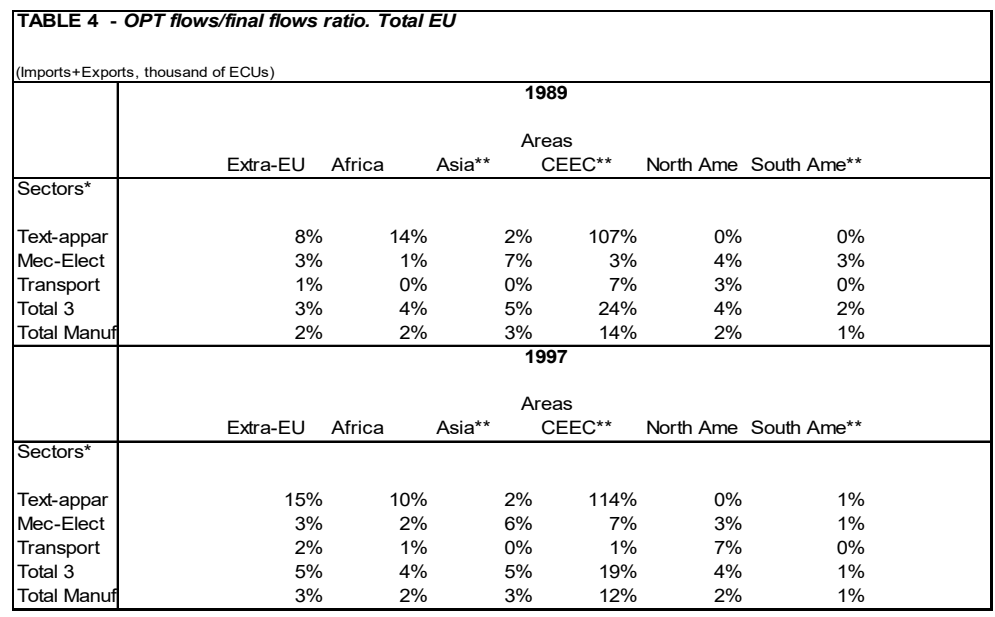

Source: Comext

${ }^{16}$ RoEmer (1977) has highlighted the role of sphere of influence factors in world trade by crossing sectoral and geographical specialization of main advanced countries. An example of sphere 


\section{The Impact of OPT on Labour Markets}

\subsection{Trade and labour markets: an open issue}

In the introduction, we have remarked that almost until the end of the 1990s the prevailing idea emerging in the debate on globalisation and jobs was that the adverse shift in labour demand for unskilled workers which has occurred in OECD countries has to be attributed to technological change rather than international trade. This conclusion mainly derived from the inconsistencies stressed by trade theorists between the standard model of international trade (HOS model) and the empirical evidence concerning the industrial adjustment in the United States.

However, following Wood (1994), we have also stressed the risk of understating the effects of trade on labour markets if product heterogeneity is not adequately examined or, in other words, if the role of "non-competing trade" is disregarded. Celi and Smith (1999) and Celi and Segnana (2000), building on the Wood's warning, offered a new perspective of analysis in which the labour market effects of two forms of non-competing trade flows were evaluated: i) trade which is intra-industry (IIT) at 3-digit level of disaggregation, but inter-product trade at 8 -digit, ii) IIT with quality product dif-

of influence factors acting in OPT is represented by France OPT flows in Textile-apparel. In 1989 a large proportion of those flows were oriented to North Africa, indicating an evident Roemer-type link between the country and a geographical area characterized by previous colonial relationship with France. A recent work exploring the colonial trade linkages and their effects on the geographical pattern of trade of former British and French colonies with the rest of the world is the paper of BERTHOU and EHRHART (2013). 
ferentiation (VIIT, vertical intra-industry trade). They found that the impact of these two types of trade was significant in the case of Italy in the 1990s.

In other words, CELI and SMITH (1999) suggested that a way of reconsidering the importance of the labour market effects of international trade is to look at vertical product differentiation. Actually, according to the authors, the reallocative and distributive effects of IIT are neutral only if the product differentiation is of a horizontal type, that is an exchange of varieties of a similar product differentiated by attributes in a given quality level between countries with similar factor endowments and similar income levels. But if the product differentiation is of a vertical nature the impact of IIT is not neutral. In fact, it is reasonable to suppose that differences in quality are associated with differences in skill content, so that high (low) quality products incorporate high (low) content of skilled labour. In this case, trade among countries with different endowments of human skill induces movements of specialization along the quality spectrum for each sector. In other words, trade induces factor substitution within sectors at the level of individual products where factors are human capital, knowledge, immaterial and specific factors, etc. Conventional factor content of trade (FCT) studies failed to capture the impact of international trade within industries because they assumed the sector as the unity of analysis. In particular, these studies failed to capture the impact associated with: 1) interproduct trade within-industry, 2) vertical intra-product trade (quality differentiation).

The model presented by CELI and SMITH dealt with the issue of aggregation by providing an account of intra-industry trade that was based on comparative advantage. In the model, each sector is modelled as containing a continuum of techniques. This permits factor substitution within sectors at 
the level of the individual product, allowing a much richer range of substitution effects. The model explains both intraindustry trade and inter-industry trade as deriving from the factor endowment differences between countries, it implies that trade will affect inequality, and the properties of the model are consistent with the three stylised facts which LAwRENCE and Slaughter use to dismiss the Stolper-Samuelson explanation of American wage change. Applying the model to trade between Italy and 'non-advanced countries' and inferring the factor content of intra-industry trade from the intersectoral relationship between factor intensity and the average unit values of exports, CELI and SMITH found that the labour market effects of intra-industry trade add significantly to the estimated factor market impact of trade.

FEenstra (1998) has emphasized that another important source of underestimation of the labour market effect of international integration is the lack of an adequate consideration of the vertical disintegration of production within-industry on international scale:

“...Outsourcing has a qualitative similar effect on reducing the demand for unskilled relative to skilled labor within an industry as does skilled-biased technological change. This insight has several important implications. First, we should not assess the proximate cause of the decline in employment and wages of unskilled workers by attributing all within-industry shifts in labor demand to technology, and allowing trade to operate only via between-industry shifts. This was the approach taken by Lawrence and Slaughter (1993) and Berman, Bound and GRILICHES (1994), both of whom considered only trade in final goods. In that context, it is correct that international trade must affect labor demand through interindustry shifts. But as soon as trade in intermediate inputs is permitted, as with outsourcing, then changes in the demand for labor within each industry can occur due to trade, as well... ${ }^{17}$,

${ }^{17}$ Feenstra (1998), page 41. 
Conceptually, the observation of FEENSTRA about the labour market impact of trade flows originating from international fragmentation of production is important but the implementation of empirical estimates about this phenomenon represents a very difficult task, given the lack of systematic information about the international relocation processes acting within-industry ${ }^{18}$. The present work offers an attempt to deal with this empirical issue ${ }^{19}$. The availability of a powerful data

${ }^{18}$ However, since 1990s, data sets with detailed information on production and trade at the firm level became available in many countries (in advanced and also in developing economies). In recent years, such availability of firm-level data has allowed to test the socalled "new new" theory of international trade (NNTIT), inaugurated by the seminal contribution of MeLiTz (2003). The main idea of the NNTIT is that international trade leads to an "upgrading" of exporting firms. Therefore, in order to establish a nexus between compositional changes within-industry induced by exporting and the trade and jobs debate, it would be necessary to show that higher-quality firms (more productive firms) activate a higher demand for skilled and, consequently, induce a rise in inequality. Using micro data, BERNARD and JENSEN (1997) found that exporting is a skill-intensive activity in the case of United States and HARrISON, and HANSON (1999) found similar results in the case of Mexico. GOLDBERG and PAVCNIK (2007) provided a methodological discussion and micro data-based empirical evidence about the distributional impact of globalization in developing countries. Recently, with the growing relevance of the phenomenon of offshoring in terms of trade in services, the focus of the literature exploring the link between globalization and labour markets has changed, moving away from the traditional comparison between the wages of white collars and those of blue collars. Recent contributions instead use data based on occupational classifications or micro-level datasets that allows to evaluate the "tradability" of different tasks or how tasks are routine activities and can easily been computerized (and relocated). On this regard, the theoretical reference of this new strand of literature is the tasks-based model of Grossman and Rossi-Hansberg (2006).

${ }^{19}$ The approach followed in this paper doesn't use micro data 
set for EU countries (Eurostat-Comext) distinguishing OPT - a form of vertical trade - from final flows and of an empirical methodology (offered by CELI and Smith, 1999) able to estimate the factor content of intra-industry trade permit together a quantitative measurement of the impact of vertical trade. In CELI and SMITH's paper, the calculation of the factor content of IIT focussed on flows of final goods for the reason that the emphasis was on quality differentiation. Now the analysis of labour market effects of IIT goes further and the FCT methodology at the 8-digit level is applied to a new data set relating to trade flows of a different nature in comparison with final flows, specifically trade flows originating from vertical fragmentation of production. We expect that the labour market effects of OPT are larger than final flows since it is reasonable to assume that EU firms relocate the less skill intensive segments of production to the CEECs.

In the previous section of this paper we observed that the OPT share of trade flows is trivial in aggregate but it is relevant in specific sectors and markets. In the case of the CEECs in the Textile-apparel sector OPT flows are even bigger than final flows. So any attempt to calculate the effects of EU trade with CEECs on EU labour markets has to give this aspect due consideration. In the next section, the differential impact of OPT flows in comparison with final flows is estimated by looking at EU trade with CEECs in the Textile-apparel-footwear-leather sectors. The interest of this empirical application is twofold: on the one hand it represents a way to treat, at the empirical level, an important analytical issue that has recently emerged in the debate on trade and jobs; on the other hand it gives the opportunity to transpose

but is in the tradition of factor content of trade methodology opportunely modified in order to take account of within-industry adjustment. 
the debate on "liberalization and the labour markets", developed in the late 1980s and the 1990s especially in the US, to the EU with particular regard to the dynamics of integration with CEE countries.

\subsection{An empirical application}

\subsubsection{The structure of trade flows}

A preliminary investigation of the link between trade and labour markets requires us to look carefully at the nature of trade flows. In other words, a useful task is to identify the share of trade flows which has an impact on labour markets. Obviously, in this task the level of aggregation matters. If we adopted a conventional approach based on the Heckscher-Ohlin model of inter-industry trade applied to three-digit sectors we would exclude from FCT calculations the share of trade consisting of intra-industry flows (IIT), that is to say offsetting flows of imports and exports within 3-digit sectors which have zero effect in the factor content calculation. But in following the conventional wisdom we risk an underestimation of the trade impact because of the part of IIT flows which, on the contrary, could have a labour market effects. This part consists of: 1) inter-product flows within-industry, 2) intra-product flows differentiated by quality ${ }^{20}$.

${ }^{20}$ The following example illustrates how trade impact may be misjudged because of a lack of information about the two points remarked above. Suppose that at 3-digit level of aggregation the share of IIT in total trade is $60 \%$; conventionally, only $40 \%$ of total trade (inter-industry trade) has an impact on labour markets. But if $30 \%$ of total trade is vertical IIT (half of the overlap involves 2 -way trade flows of different qualities), the share of total trade inducing 
In order to take account of the two types of trade flows disregarded in conventional FCT studies, here two classes of indices are calculated: 1) IIT indices at the 3 and 8 digit level to evaluate to what extent the level of aggregation hides inter-product trade; 2) 8-digit IIT indices distinguishing vertical and horizontal components in order to single out 2-way trade flows differentiated by quality.

The methodology used to disentangle horizontal and vertical IIT was based on the approach suggested by GrEeNAWAY, Hine and Milner (1995). These authors - following AbD-EL-Rahman (1991) - decomposed the unadjusted Grubel-Lloyd (G-L) index in vertical and horizontal IIT (VIIT an HIIT, respectively) by using information deriving from unit values calculated at the 5 -digit level (according to SITC) ${ }^{21}$. The recourse to unit values (UV) of exports and imports is a way to collect information about the quality of traded goods. In our calculations, unit values are computed according to a very narrow 8-digit definition of product ${ }^{22}$. The criterion used to discriminate between the two components of IIT was the inclusion in the numerator of G-L index of only the trade flows of those product categories whose unit value of exports relative to the unit value of imports is outside (or within) a certain range of variation $( \pm 15 \%)$. Where the absolute value of the difference between the unit values for exports

effects on labour markets increases to $70 \%$. This latter percentage increases further if the IIT index was calculated at a greater level of disaggregation, allowing to capture inter-product trade.

${ }^{21}$ An alternative method of disentangling horizontal and vertical IIT was suggested by CEPII (1995).

${ }^{22}$ The controversial aspects of the use of UV as a proxy of prices are well-known in the literature. In the present context, however, considering that UVs are related to 8-digit level categories, the risk of distortions caused by aggregation is ruled out. 
and imports was more (less) than 15\%, the share of vertical (horizontal) IIT was obtained ${ }^{23}$. One can further distinguish

${ }^{23}$ If $c$ denotes all 8-digit level product categories in manufacturing industry $j$, the Grubel-Lloyd IIT index is:

$$
I I T_{j}=1-\frac{\sum_{c}\left|X_{c}-M_{c}\right|}{\sum_{c}\left(X_{c}+M_{c}\right)}
$$

where $X_{c}$ and $M_{c}$ denote the value of exports and imports respectively. The index (1) can be rearranged as:

$$
I I T_{j}=\frac{\sum_{c}\left(X_{c}+M_{c}\right)-\sum_{c}\left|X_{c}-M_{c}\right|}{\sum_{c}\left(X_{c}+M_{c}\right)}
$$

The numerator of index (1b) can be recalculated by considering only those categories in which the absolute value of the difference between the UV for exports and imports is greater than 15\%; that is, $1.15<\mathrm{UVX}_{\mathrm{c}} / \mathrm{UVM}_{\mathrm{c}}<0.85$. Consequently, index (1b) becomes the share of vertical intra-industry trade in total trade:

$$
V I I T_{j}=\frac{\sum_{c v}\left(X_{c v}+M_{c v}\right)-\sum_{c v}\left|X_{c v}-M_{c v}\right|}{\sum_{c}\left(X_{c}+M_{c}\right)}
$$

Finally, the same procedure can be adopted to obtain the share of horizontal intra-industry in total trade. In this case the numerator of the index is calculated by considering the items where $0.85<\mathrm{UVX}_{\mathrm{c}} / \mathrm{UVM}_{\mathrm{c}}<1.15$; that is, those residual categories where quality differences between exports and imports are not very pronounced. The result is:

$$
\operatorname{HIIT}_{j}=\frac{\sum_{c h}\left(X_{c h}+M_{c h}\right)-\sum_{c h}\left|X_{c h}-M_{c h}\right|}{\sum_{c}\left(X_{c}+M_{c}\right)}
$$

Under the above assumptions, it is natural that:

$$
I T_{j}=\operatorname{VIIT}_{j}+\text { HIIT }_{j}
$$


between 'VIIT+' trade, where the unit values of the export flow are greater (by at least 15\%) than the import unit value; while 'VIIT'-, trade describes the case where it is import unit values that are larger.

Intra-industry trade indices have been calculated in the case of German and Italian trade with the CEECs in 1997. The sectors considered belong to the aggregate Textile-apparel-footwear-leather ${ }^{24}$. The trade structure emerging from the calculation of IIT indices is reported in the four figures below. Figures 1 and 2 refer to final flows (proxied by non-OPT flows) of Germany and Italy respectively. Figures 3 and 4 concern OPT flows for the same countries.

\subsubsection{The structure of final trade flows}

In the case of German final flows (figure 1), IIT calculated at 3-digit level represents $55 \%$ of total trade. This means that inter-industry trade, that is HO-type trade, corresponds to $45 \%$ of total flows. But if we calculate the Grubel-Lloyd index at the 8 -digit level, then the 2-way trade drops to $31 \%$; consequently HO trade rises to $69 \%$, indicating that the 3 -digit calculation hides $24 \%$ of trade flows which is inter-product trade (that is IIT at the 3 -digit but HO trade at the 8-digit).

In addition, if we divide the 8-digit Grubel-Lloyd index $(31 \%)$ into the vertical and horizontal components, we see that trade flows differentiated by quality predominate (VIIT $=25 \%$, HIIT $=6 \%)^{25}$. Only a small residual fraction of total

${ }^{24}$ We consider 10 3-digit NACE sectors and all 1588 8-digit products belonging to those sectors.

${ }^{25}$ VIIT can be further divided into VIIT $^{+}$and VIIT ${ }^{-}$. The first component indicates trade flows where UVs of exports are bigger 
trade, HIIT $=6 \%$, has no effect on labour markets: a quite different number from that deriving from a mere conventional 3-digit calculation (IIT $=55 \%$ ).

Figure 2 shows that the structure of Italian final flows is quite similar to the case of Germany and no particular comment needs to be made. In the end, the analysis of trade structure with reference to final flows suggests that the level of aggregation is important and that any FCT calculation has to hold this aspect in due consideration. This conclusion is in line with results obtained in the case of Italian manufacturing trade with less advanced countries (see Celi and Smith, 1999 and Celi and Segnana, 2000).

Figure 1 - Structure of German trade with CEEC in

Textile-apparel-footwear-leather sectors - Final flows - 1997

\section{Final Flows Germany}

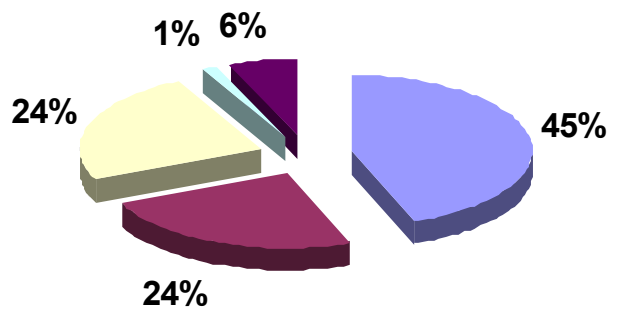

Legenda:

$\mathrm{HO}(3$-digit $)=45 \% \quad$ IIT (3-digit), HO (8-digit) $=24 \% \quad \mathrm{VIIT}^{+}=\mathbf{2 4} \%$ VIIT $^{-}=\mathbf{1} \% \mid$ HIIT $=\mathbf{6} \%$

than UVs of imports. The second component refers to trade flows where it is UVs of imports that are larger. In figure 1, we note that 
Figure 2 - Structure of Italian trade with CEEC in

Textile-apparel-footwear-leather sectors - Final flows - 1997

\section{Final Flows Italy}

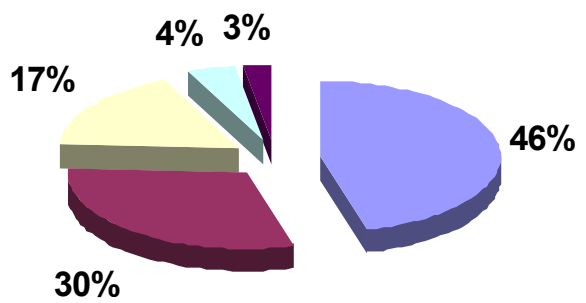

Legenda:

$\mathrm{HO}(3$-digit $)=46 \% \quad \mathrm{IIT}$ (3-digit), $\mathrm{HO}(8$-digit $)=30 \% \quad \mathrm{VIIT}^{+}=17 \%$ $\mathrm{VIIT}^{-}=4 \% \mid$ HIIT $=3 \%$

\subsubsection{The structure of OPT flows}

When we apply the same trade structure analysis to OPT flows, we have to expect different results from those deriving from final flows. Although the methodology based on the computation of IIT indices at the 8-digit level turns out to be appropriate also in the case of OPT flows, we have to introduce some qualifications concerning the specific nature of this type of trade.

$\operatorname{VIIT}^{+}(24 \%)$ prevails over $\operatorname{VIIT}^{-}(1 \%)$. This result is in line with what we expect for final trade flows between EU countries and CEECs, because it is reasonable to assume that the quality of EU exports of final goods is higher than the quality of CEEC exports of final goods. As discussed in the next section, this assumption has to be amended in the case of OPT flows. 
On the one hand it is reasonable to presume that the computation of inter-product trade at the 8-digit level allows us to capture, to some extent, vertical disintegration of production inside OPT flows. On the other hand the approach aiming to disentangle horizontal and vertical components inside IIT at the 8 digit level turns out to be more problematic to interpret when it is applied to the case of OPT flows. In EU-CEEC OPT the UVs of imports are higher on average than the UVs of exports. At first sight this seems puzzling because it would be more reasonable to assume that the quality of EU exports is higher than CEEC exports. However this result is not surprising because we are observing trade flows deriving from relocation of the phases of production abroad and not the trade flows of final goods. In other words, in the case of OPT in textile, apparel and leather, the difference between the export UV and the import UV of a particular 8-digit product could signal the fact that the commodity imported is more processed than the commodity exported, and not a mere example of quality differentiation as in the case of final goods ${ }^{26}$.

This problem may be rather specific to textile, apparel, footwear and leather, where the successive stages of production are applied to a largely unchanged amount of physical material. In sectors such as electronics, with a less 'linear' production pro-

${ }^{26}$ We have calculated the ratio $\mathrm{UV}^{\mathrm{M}} / \mathrm{UV}^{\mathrm{x}}$ at the 8-digit level and averaged for the total aggregate "Textile-apparel-footwear-leather" across 8-digit commodities in the case of final flows and OPT flows respectively. In both cases of Germany and Italy final flows show a ratio $<1$ while OPT flows show a ratio $>1$. This result is what we expect because final goods exported by Germany or Italy are on average more skill intensive than final goods imported from CEECs, while in OPT flows the intermediate goods exported from Germany or Italy to be processed in CEECs come back as imports with much added value reflected in a higher $\mathrm{UV}^{\mathrm{M}}$ on average. 
cess we might well have high value, high quality components sent abroad for assembly into a lower unit-value final product.

The structure of OPT flows displayed in figures 3 and 4 confirms the qualifications above reported. Figure 3 shows that, in the case of Germany, even at the 3-digit level HO-type trade is the predominant part of total trade $(75 \%)$. From this result we can also infer that an FCT calculation carried out at the 3-digit level will produce a balanced trade impact greater than that of final flows. Figure 3 also shows, although to a lesser degree than for final flows, that inter-product trade and VIIT augment $\mathrm{HO}$ trade (11\% and $10 \%$ more respectively). As we expect for OPT flows, for the reasons above discussed, we note that VIIT ${ }^{-}$prevails in VIIT. In other words, 8 digit 2-way trade flows where the UVs of exports are lower than UVs of imports prevail over $\mathrm{VIIT}^{+}$ (where it is the UVs of imports that are lower).

Figure 3 - Structure of Germany trade with CEEC in Textile-apparel-footwear-leather sectors - OPT flows - 1997

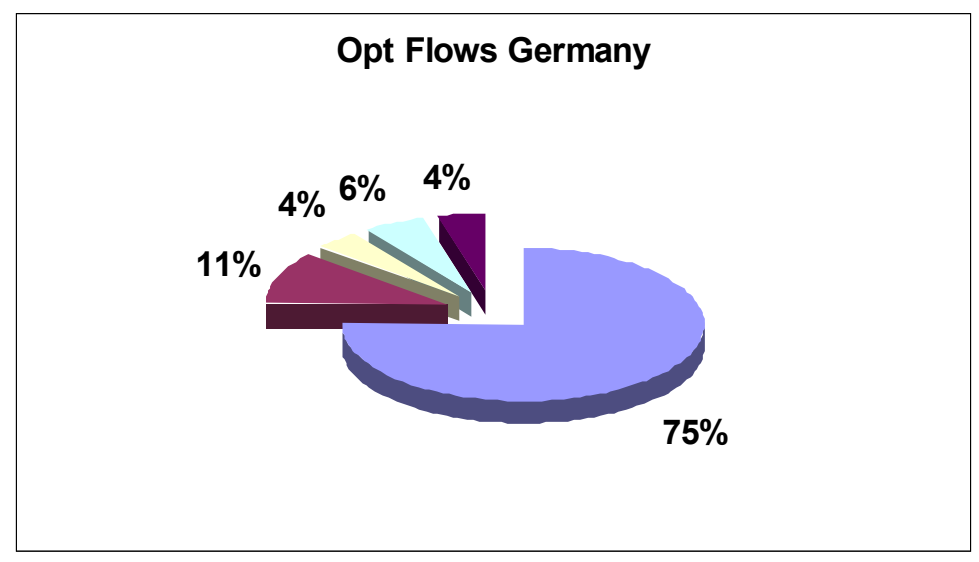

Legenda:

$\mathrm{HO}\left(3\right.$-digit) $=75 \% \quad \mathrm{IIT}$ (3-digit), $\mathrm{HO}\left(8\right.$-digit) $=11 \% \mid \mathrm{VIIT}^{+}=4 \%$ VIIT $^{-}=6 \% \mid$ HIIT $=4 \%$ 
In the end, in the case of German OPT, analysis of the flow structure suggests that the trade impact might be more substantial than in the case of final flows but, at the same time, the level of aggregation seems to play a less relevant role in comparison with final flows.

However, when we look at Italian OPT flows, we observe that IIT is bigger than in the case of Germany (42\% against $25 \%$ ). This result confirms that the two countries have different models of outsourcing towards CEECs. In the case of Italy, a relevant proportion of the re-imports of apparel consists of products originally exported under the heading "apparel". In general, Italy relocates to CEECs the segments of the production process very close to the final stage of output, while Germany transfers to CEECs a broader spectrum of productive segments in order to re-import final goods ${ }^{27}$.

Therefore, given the higher level of IIT in OPT flows, in the case of Italy the issue of aggregation seems to play a more important role. In effect, figure 4 shows that IIT at the 3-digit level which is inter-product trade at the 8-digit level amounts to $15 \%$. In addition VIIT (that is 8 -digit 2 -way trade flows differentiated by quality) adds up to $22 \%$. Also in the case of Italy, VIIT ${ }^{-}$prevail over VIIT $^{+}$but to a much greater degree than in the case of Germany (16\% against $6 \%)$.

Especially in the case of Italy, the structure of OPT flows suggests that any evaluation of the labour market effects of OPT has to take account of the impact of IIT. As it will be illustrated in the next section, the FCT methodology based on the use of UVs at the 8-digit level in order to infer skill-intensity within industries, allows us to capture the labour market impact of inter-product trade that, in the context of OPT flows, represents a form of vertical disintegration of production.

${ }^{27}$ Baldone, Sdogati and Tajoli (1999). 
Figure 4 - Structure of Italian trade with CEEC in

Textile-apparel-footwear-leather sectors - OPT flows - 1997

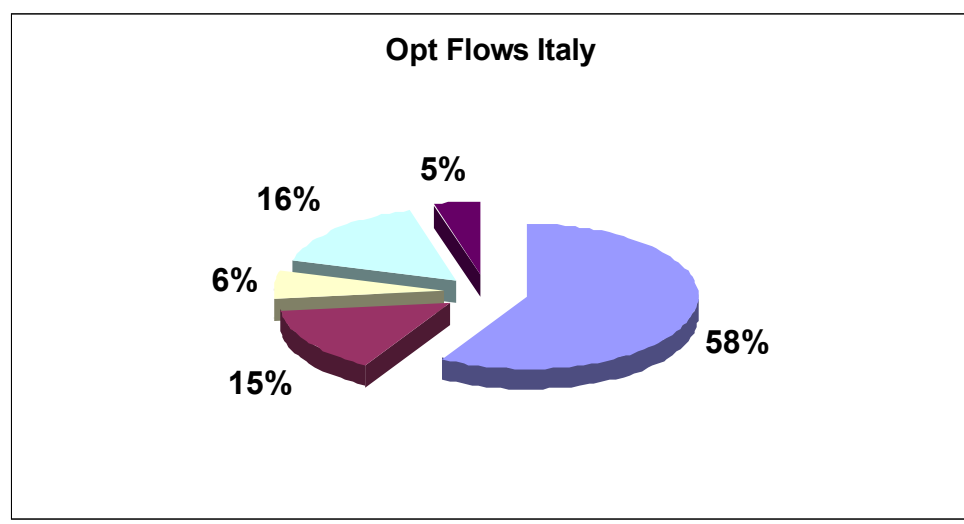

Legenda:

$\mathrm{HO}(3$-digit $)=58 \% \quad$ IIT (3-digit), HO (8-digit) $=\mathbf{1 5} \% \quad \mathrm{VIIT}^{+}=\mathbf{6} \%$ $\mathrm{VIIT}^{-}=16 \% \mid$ HIIT $=\mathbf{5} \%$

\subsubsection{FCT analysis}

This section presents an evaluation of the differential labour market impact of OPT flows in comparison with final flows. In particular, results deriving from the 3-digit FCT calculation (conventional procedure) are compared with those obtained from the 8-digit computation. The two factors considered are skilled and unskilled labour. In the case of the 3-digit calculation, the availability of industry data (Eurostat data set with sectors defined according to NACE) enables us to obtain input coefficients: the proxy for the skilled labour (unskilled labour) coefficient is obtained as the ratio between non manual (manual) workers and turnover. At the 8-digit 
level no systematic industry data is available. Therefore the following estimate procedure suggested by CELI and SMITH (1999) - based on unit values of trade flows in order to compute input coefficients at the 8-digit level - is here adopted. Firstly a cross-sector regressions at the 3-digit level are carried out in order to verify whether unit values (a proxy for quality) could explain skill intensity:

$$
\begin{aligned}
& \text { SKY }=\alpha_{0}+\alpha_{1} \text { LUVXW } \\
& \text { UNY }=\alpha_{0}+\alpha_{1} \text { LUVXW, }
\end{aligned}
$$

where:

SKY = 3-digit skilled labour coefficient

(non manual workers/turnover)

$\mathrm{UNY}=3$-digit unskilled labour coefficient

(manual workers/turnover)

LUVXW $=\log$ of unit value of export at 3-digit level ${ }^{28}$

Regression results ${ }^{29}$ are the following:

$$
\begin{array}{ccc}
\text { SKY }= & 1.329+0.318 \text { LUVXW } & \mathrm{R}^{2}=0.40 \\
& & \\
\mathrm{UNY}= & 4.756+0.346 \text { LUVXW } & \mathrm{R}^{2}=0.09
\end{array}
$$

(t-statistics in parentheses)

${ }^{28}$ Note that the regressor expressed at the 3-digit level has been calculated at 8-digit level and averaged for each sector across all 8-digit commodities. Therefore information at 8-digit is not lost at 3-digit.

${ }^{29}$ Regressions were carried out on 77 observations referred to Italy (from Nace code 260 to 495). 
The constant term and the LUVXW coefficient show an acceptable level of significance ${ }^{30}$. Hence, if there is a statistically significant association between skill intensity and unit values at 3 digits, and if we assume that this relationship also holds at 8 digits, we can use the above-estimated equations to obtain 8-digit SKY and UNY via 8-digit unit values ${ }^{31}$. Note that the above equations can be used to derive coefficients of trade partners (CEECs) when the unit values of imports are applied in the place of the unit values of exports in accordance with a Wood-type approach ${ }^{32}$.

${ }^{30}$ At first sight the positive coefficient in the second regression may seem surprising, but it is easily checked that the two regressions together imply that the ratio of non-manual to manual labour is increasing in the unit value of exports, which is consistent with the notion of product quality being skill-intensive. It is also acceptable that higher quality products require more of both kinds of labour.

31 The best procedure to derive 8-digit coefficients is to adjust the above estimated equations by inserting an error term obtained as the difference between the estimated value and the observed value for each 3-digit coefficient. Implicitly in this procedure we assume that each particular 3-digit error term approximates the error term of all 8-digit categories belonging to that particular 3-digit sector:

$$
\begin{aligned}
& \mathrm{SKY}_{8 \text {-digit }}=1.329+0.318 \mathrm{LUVX}_{8 \text {-digit }}+\mathrm{e}_{3 \text {-digit }} \\
& \mathrm{UNY}_{8 \text {-digit }}=4.756+0.346 \mathrm{LUVX}_{8 \text {-digit }}+\mathrm{e}_{3 \text {-digit }}
\end{aligned}
$$

32 Wood (1994), as reported above, contested conventional FCT studies, arguing that these studies, by using the factorial coefficients matrix of developed countries as the estimator of factor content for both imports and exports, have underestimated the unskilled labour content of less advanced countries (LACs) exports to developed countries. Consequently, they have undervalued the displacement effect of the developed countries' trade with LACs on unskilled labour demand in developed countries. He suggested using different input coefficients for imports and exports respectively. 
Therefore the previous procedure allows us to conduct two types of FCT calculation. The first calculation (HO-8 method or, if you want, un-Wood method) attempts to calculate the labour market effects of trade that is measured as intra-industry trade at the 3-digit level but as inter-product trade at the 8-digit level by imputing labour input coefficients to each 8-digit commodity, but the same input coefficients to exports and to import substitutes. The second calculation (VIIT method or, if you want, Wood method) goes further: by imputing separate coefficients to exports and import substitutes, it allows for factor market effects from vertical intra-industry trade at the 8-digit level that is from intra-product flows differentiated by quality.

The methodology above described has been applied to the case of Italy-LAC trade in final goods. How is the same approach to be interpreted when it is applied to the context of EU-CEEC OPT flows?

As discussed in the previous section, in the case of textile, apparel, footwear and leather OPT flows the probable negative difference between export UV and import UV of a particular 8-digit good doesn't necessarily represent a lower quality of exports in comparison with imports but it could represent the mere fact that the commodity imported is more processed than the commodity exported. So when the method is applied to OPT flows a probable outcome is that the FCT calculation via VIIT approach will produce a smaller trade impact in terms of relative demand for skilled labour in comparison with the HO-8 approach. This outcome is the opposite of the result obtained in the case of final flows.

An example can clarify this point. Suppose that 1000 tons of shirts are exported from Italy to Romania in order to be processed and then re-imported in Italy. In HO-8 methodo- 
logy, the impact on Italian labour market is zero because the same input coefficients (extrapolated from $U^{\mathrm{X}}$ ) are applied to exports and to import substitutes. In VIIT methodology, where different input coefficients are imputed to import substitutes and exports, because $\mathrm{UV}^{\mathrm{M}}>\mathrm{UV}^{\mathrm{X}}$ we calculate a decrease in labour demand for skilled and unskilled labour and a decline in relative demand for skilled labour in Italy.

In other words, when we apply the VIIT method to OPT flows we have to expect results reflecting simultaneously: 1) quality differentiation, for each 8-digit commodity whose exports and imports are "un-linked" in terms of productive processes; 2) vertical disintegration of production when exports and imports are "linked". It is the OPT-specific effect in point 2 that tend to overestimate the skill-intensity of CEEC production, for the reason above discussed. Clearly this result contrasts with what we should expect when we study the impact of EU-CEEC OPT on EU labour markets, namely an increase in relative demand for skilled labour due to the relocation of less skill-intensive activities to the CEECs. In reality the VIIT method implies an underestimation of the impact of OPT on EU labour markets.

A possible adjustment for VIIT method could be the use of UVs of final flows in place of UVs of OPT flows to calculate the labour market impact of OPT. This correction aims to limit the bias above discussed by using UVs of trade flows which are unlinked in terms of production process. A sort of counterfactual assumption is implicit in this correction: suppose to treat OPT flows like final flows, what would be the labour market effect deriving from the pattern of OPT? Obviously, this adjustment is based on the strong hypothesis that there is no vertical disintegration in final flows.

The "t-shirt example" above reported is the case of a 
commodity exported and reimported in the same 8-digit category. A common circumstance in OPT flows is also the case of a commodity exported and re-imported under a different 8 -digit code. In this case, even if there is no quality differentiation at all, the UV of the good reimported will increase as a result of outward processing. In other words, because the good is reimported in a different 8-digit code from the one in which it was exported, so we don't actually identify the fact that $\mathrm{UV}^{\mathrm{M}}>\mathrm{UV}^{\mathrm{X}}$, but we have still to consider that the effect of outward processing is present in $\mathrm{UV}^{\mathrm{M}}$ in any case. Consequently, when we look at this inter-product trade and try to estimate its impact on labour markets, we have to acknowledge that the HO-8 digit method produces biased estimates as well as VIIT method. In the HO-8 digit method $\mathrm{UV}^{\mathrm{x}}$ are used to estimate the same input coefficients for exports and import substitutes. But the $\mathrm{UV}^{\mathrm{x}}$ of the more processed good reimported (clothing, for example) will be higher than the UV ${ }^{\mathrm{x}}$ of the less processed good exported (textile) only in virtue of the value added. This circumstance will tend to overestimate the skill content of CEECs exports to EU countries. Therefore, we have to be conscious that the method illustrated above in order to measure the impact of intra-industry trade on labour markets produces biased estimates when applied to OPT flows.

Table 5 and table 6 report FCT results obtained for Germany and Italy respectively. Estimates refers to the 8-digit HO method and the VIIT method with/without adjustment. The effect of trade is presented in terms of changes of relative demand for skilled. 
Table 5 - Impact of German trade with CEECs on German labour market $-1997^{a}$

3-digit balanced trade impact

Final flows: skilled $=+0.36 \%$, unskilled $=-0.58 \%$, relative demand for skilled $=+0.94 \%$

Opt flows: skilled $=-1.40 \%$, unskilled $=-3.81 \%$, relative demand for skilled $=+2.38 \%$

$(+1.58 \%)^{\text {b }}$

8-digit HO balanced trade impact

Final flows: skilled $=+0.16 \%$, unskilled $=-0.84 \%$, relative demand for skilled $=+1.00 \%$ Opt flows: skilled $=+1.22 \%$, unskilled $=-1.51 \%$, relative demand for skilled $=+2.73 \%$

8-digit with VIIT balanced trade impact

$(+1.82 \%)^{\mathrm{b}}$

Final flows: skilled $=-0.33 \%$, unskilled $=-0.78 \%$, relative demand for skilled $=+1.11 \%$

Opt flows: skilled $=+1.18 \%$, unskilled $=-1.53 \%$, relative demand for skilled $=+2.71 \%$

$(+1.80 \%)^{\mathrm{b}}$

8-digit with VIIT balanced trade impact with adjustment ${ }^{c}$

Opt flows: skilled $=+1.18 \%$, unskilled $=-1.53 \%$, relative demand for skilled $=+2.88 \%$

$(+1.92 \%)^{\mathrm{b}}$

(a) Trade impact is expressed as percentage of employment

(b) Factorcontent of OPT flows scaled down in proportion to the excess of OPT over final flows

(c) By using UVs of final flows in place of UVs of OPT flows

In the case of Germany, FCT results confirm our expectations based on the structure of trade flows: i) much larger effects in OPT than in final flows because inter-industry trade is bigger in OPT; ii) 3-digit FCT calculation captures the most effect. This result is partially due to the greater magnitude of OPT flows in comparison with final flows (see table 2-A in annex). However when factor content of OPT is scaled down in proportion to the excess of OPT over final flows the stronger $\mathrm{HO}$ effects of OPT flows still remain: $1.58 \%$ against 
$0.94 \%$ (see results in brackets in table 5).

As we move from the 3-digit to the $\mathrm{HO} 8$-digit calculation, the differential between OPT impact and final flow impact increases (from $+153 \%$ to $+173 \%$, or from $68 \%$ to $82 \%$ when OPT flows are scaled down proportionally over final flows). This is the fragmentation-driven effect captured by FCT calculation based on inter-product trade.

The inclusion of VIIT effect in 8-digit FCT calculations increases trade impact in the case of final flows but not in the case of OPT flows. This result confirms the idea above reported that the FCT calculation using different coefficients for exports and imports incorporates, in the case of OPT flows, an anti-HO effect for the reason that in $\mathrm{OPT} \mathrm{UV}^{\mathrm{M}}>\mathrm{UV}^{\mathrm{x}}$ on average. But if the 8-digit computation of OPT impact including VIIT effect is carried out by introducing the adjustment above suggested then the impact increases (compare $2.88 \%$ against $2.71 \%$ ).

When we look at Italy (table 6), the results essentially resemble the pattern associated with Germany. At the 3-digit level the labour market effects of OPT are stronger than in the case of final flows (much stronger if the factor content of OPT is scaled up in proportion over the greater dimension of trade in final goods) $)^{33}$. The positive differential between the OPT impact and the final flows impact grows when we turn to HO 8-digit FCT calculation. In proportion this increase is bigger than in the case of Germany if the comparison is based on factor content of OPT adjusted to take account of the excess of final flows over OPT. As mentioned before, this outcome corroborates the importance of a disaggregated evaluation in the case of trade impact on Italian labour

${ }^{33}$ In the Italian case, OPT flows are smaller in comparison with final flows. In 1997 the ratio between OPT flows and final flows is 0.75 . See table $5 \mathrm{~A}$ in annex. 
markets. Finally, when we also consider the impact of VIIT in the 8-digit FCT calculation the effects of OPT on the Italian labour market decrease to a greater degree than in the case of the German labour market. This result is consistent with the previous analysis of the structure of trade flows in which we remarked on the more important share of $\mathrm{VIIT}^{-}$in the case of Italian OPT ${ }^{34}$. However, when the UVs of OPT are replaced with the UVs of final flows, the impact of OPT taking account of VIIT effect goes up (compare $0.51 \%$ against $0.45 \%$, or $0.72 \%$ against $0.64 \%$ when factor content of OPT is scaled up in proportion to final flows).

In conclusion, the FCT analysis applied to the case of German and Italian trade with the CEECs in the Textile-apparel-footwear-leather sectors suggests that the labour market effects of OPT flows is stronger than the impact of final flows. This result is confirmed both at the 3 and the 8 digit level of aggregation.

${ }^{34}$ In the Italian case, the possibility of a commodity exported and reimported in the same 8-digit category is more probable than in the German case. This circumstance contributes to reduce the OPT impact on the relative demand for skilled labour. In effect, when we look at disaggregated data at the 8-digit level in order to single out Italian OPT commodities in which $\mathrm{UV}^{\mathrm{M}}>\mathrm{UV}^{\mathrm{x}}$ we observe that the most part of this kind of flows comprises final goods such as: t-shirts (code 61099030), pullovers (code 61101031), ski-jackets (code 62019300), jackets of wool (code 62033100), trousers (code 62034235), etc. 
Table 6 - Impact of Italian trade with CEECs on Italian labour market $-1997^{\mathrm{a}}$

3-digit balanced trade impact

Final flows: skilled $=+0.11 \%$, unskilled $=-0.32 \%$, relative demand for skilled $=+0.43 \%$

Opt flows: skilled $=+0.23 \%$, unskilled $=-0.27 \%$, relative demand for skilled $=+0.50 \%$

8-digit HO balanced trade impact

$(+0.72 \%)^{1}$

Final flows: skilled $=-0.013 \%$, unskilled $=-0.38 \%$, relative demand for skilled $=+0.37 \%$

Opt flows: skilled $=+0.25 \%$, unskilled $=-0.28 \%$, relative demand for skilled $=+0.53 \%$

$(+0.75 \%)^{\mathrm{b}}$

8-digit with VIIT balanced trade impact

Final flows: skilled $=+0.043 \%$, unskilled $=-0.37 \%$, relative demand for skilled $=+0.41 \%$

Opt flows: skilled $=+0.14 \%$, unskilled $=-0.31 \%$, relative demand for skilled $=+0.45 \%$

$(+0.64 \%)^{\mathrm{b}}$

8-digit with VTIT balanced trade impact with adjustment ${ }^{\mathrm{c}}$

Opt flows: skilled $=+0.14 \%$, unskilled $=-0.31 \%$, relative demand for skilled $=+0.51 \%$

$(+0.72 \%)$

(a) Trade impact is expressed as percentage of employment

(b) Factor content of OPT flows scaled up in proportion to the excess of final flows over OPT

(c) By using the UVs of final flows in place of the UVs of OPT flows

\section{Conclusions}

In this paper the impact of OPT between EU countries and the CEECs on EU labour markets in the 1990s has been analysed.

A preliminary overview of OPT in EU countries has shown that on aggregate this type of trade still represents a small fraction of total trade. Nevertheless OPT flows displayed a growth rate much more pronounced in comparison 
with the dynamics associated with final flows $(20 \%$ against $7.5 \%$ on a yearly basis in the period 1989-1997), confirming the findings mentioned in recent studies of an increasing importance of vertical flows in world trade since the 1990s.

When the sectoral composition of OPT flows is considered, data shows that only three main aggregates account for more than $80 \%$ of total manufacturing industry flows: Machinery, Textiles-apparel and Transport. Interestingly, this sectoral concentration of OPT flows links up with a geographical specialisation, indicating a straightforward international division of labour. In particular, OPT flows in Textile-apparel sector are almost entirely channelled to the CEECs, Transport OPT flows are mostly directed to North America and OPT flows in machinery are concentrated to Far Eastern countries. Globally, the CEEC area is becoming the main pole of attraction of EU OPT flows, accounting for almost $50 \%$ of total OPT. However, when we look at the relevance of OPT flows in comparison with final trade flows at the sectoral and geographical level we can note that only in the case of the CEEC area and in Textile-apparel sector is the weight of OPT remarkable.

For this reason we have chosen to evaluate the differential labour market impact of OPT flows with respect to final flows by looking at the CEECs in the Textile-apparel-footwear-leather sectors. Given that Germany and Italy accounted for the main part of EU OPT in the CEECs in those sectors in the 1990s, the trade impact has been measured with reference to the labour markets of these two countries. A preliminary analysis of the structure of trade flows has delineated different models for the two countries. In the case of Germany, IIT in OPT is smaller than in final flows; for this reason we expect a greater labour market impact associated 
with OPT flows. On the contrary, in the case of Italy, IIT in OPT is much more relevant; this suggests that, especially in the Italian case, we also need to conduct FCT analysis at the 8-digit level in order to capture the labour market impact associated with trade flows which are IIT at 3 digit but inter-product trade at 8 digit level.

In accordance with the analysis of the structure of trade flows, FCT analysis applied to the case of German and Italian trade with the CEECs in the Textile-apparel-footwear-leather sectors suggests that the labour market effects of OPT flows are stronger than the impact of final flows. This result is confirmed both at the 3 and the 8-digit level of aggregation.

The procedure based on UVs to infer input coefficients at the 8-digit level turns out to be useful in disclosing factor substitution effects due to the vertical disintegration of production in OPT, other than vertical differentiation in final flows.

However, we have remarked that the method developed by Celi and Smith (1999) to estimate the labour market effects of intra-industry trade produces biased estimates when applied to OPT flows in textile, apparel, footwear and leather. This bias is not due to trade in intermediate goods in itself because FCT methodology excludes, from the measure of labour market effects of trade, indirect inputs incorporated in imported intermediates ${ }^{35}$. The bias is due to the overesti-

35 Trade in intermediates between advanced and less developed countries raises the question whether the employment effects of trade has to be measured just in terms of value added. In general, a relevant part of the increase of developing countries exports in manufactures is due to the filling-in of gaps left free by a gradual process of "negative import substitution" in the developed economies. In the transfer of production (and of export) quotas to the developing economies, the import content does not remain unchanged; it is possible that it increase owing to the incompleteness 
mation of skill intensity associated with the fact that in these sectors prices of intermediate goods (fabrics) are lower than prices of finished goods (clothing).

But the methodological problems of these sectors do not apply generally, and in principle the FCT methodology developed in this paper can apply to trade in intermediates as well as trade in final goods, so long as unit values give unbiased estimates of product quality. Textile, clothing and footwear are unusual in having such a close physical link between the different stages of production. In sector without this unusual feature, unit values might be taken as a fairer guide to quality. In retrospect, the choice of sectors for this study was problematic and it would be highly desirable to repeat the study in other sectors.

Nevertheless, the calculation of labour market impact of IIT carried out in this work is based on a quite fragile inference whose robustness must be tested and the whole exercise suffers from the limitations of a crude FCT calculation with no price factor adjustment and other more sophisticated general equilibrium effects. Nevertheless the approach presented in this paper is an original way to deal with the issue of aggregation and heterogeneity in trade; it suggests that any accurate study of the labour market effect of trade should consider the importance of this aspect.

of the inter-industrial matrix of developing countries (GINZBURG, 1984, pag. 26). 


\section{References}

ABD-El-Rahman, K. (1991), “Firms' competitive and national comparative advantages as joint determinants of trade composition", Weltwirtschaftsliches Archiv 127(1), 83-97.

Амiтi, M. and S.J. Wei (2005), "Fear of Service Outsourcing: is it Justified?", Economic Policy, 20(42), 308-347.

_ ; - (2009), "Service Offshoring, Productivity and Employment: Evidence from the US", The World Economy, 32(2), 203220.

Ando, M. and F. Kimura (2007), "Can Offshoring Create Domestic Jobs? Evidence from Japanese Data”, CEPR, Policy Insight No. 16.

Baldone S., F. Sdogati and L. Tajoli (1999), "Patterns and Determinants of International Fragmentation of Production. Evidence from OPT between the EU and the Countries of Central-Eastern Europe", Conference of European Trade Study Group, 24-26 September, Rotterdam.

BALDwin, R.E. (1994), Towards an Integrated Europe, CEPR Press: London.

— (2006), "Globalization: The Great Unbundling(s)", in: Globalisation challenge for Europe, Secretariat of the Economic Council, Finnish Prime Minister's Office, Helsinki.

- (2011): “Trade and Industrialisation after Globalisation's $2^{\text {nd }}$ Unbundling: How Building and Joining a Supply Chain are Different and Why it Matters", NBER Working Paper No. 17716.

- (2013): "Supply-Chain Trade: a Portrait of Global Pattern and Several Testable Hypotheses", NBER Working Paper No. 18957.

Berman, E., J. Bound and Z. Griliches (1994), "Changes in the demand for skilled labor within U.S.manufacturing: Evidence from the annual survey of manufactures", The Quartely Journal of Economics, $109(2), 366-397$.

Bernard, A. B. and J. B. Jensen (1997). "Exceptional exporter performance: Cause, effect, or both?”, NBER Working Paper No. 6272. 
Berthou, A. and H. Ehrhart (2013), "Colonial Trade Spillovers", FREIT Working Paper No. 570.

Celi, G. and A. Smith (1999), "Quality differentiation and the labour market effects of international trade", CELPE Discussion Paper 50, Università di Salerno.

- and M.L. Segnana (2000), "Trade and labour markets. Vertical and regional differentiation in Italy", Labour, 14(3), 441-472.

CEPII (1995), "The development of intra-versus inter-industry trade flows inside the EU due to the internal market programme", Interim Report, 19 September, Paris.

Coluins, S. and Rodrick, D. (1991), Eastern European and the Soviet Union in the World Economy, Institute for International Economy: Washington.

Corado, C. (1994), "Textiles and Clothing Trade with Central and Eastern Europe: Impact on Members of the EC", CEPR Discussion Paper no. 1004.

Egger, H. and P. Egger (2005), "Labor Market Effects of Outsourcing under Industrial Interdependence", International Review of Economics and Finance, 14(3), 349-363.

— and M. Larch (2011), "An assessment of the Europe agreements effects on bilateral trade, GDP, and welfare", European Economic Review, 55(2), 263-279.

Ekholm, K. and K. Hakkala (2006), " The Effect of Offshoring on Labour Demand: Evidence from Sweden", CEPR Discussion Paper No. 5648.

Feenstra, R.C. (1998), "Integration of Trade and Disintegration of Production in the Global Economy", The Journal of Economic Perspectives, 12(4), 31-50.

- and G. Hanson (1996), Foreign investment, outsourcing and relative wages", in: J.N. Bhagwati, G.M. Grossman, D.A. Irwin, R.C. Feenstra, (eds.), "The Political Economy of Trade Policy: Essays in Honor of Jagdish Bhagwati", MIT Press: Cambridge, Mass. 
Freeman, R.B. (1995), "Are your wages set in Beijing?", Journal of Economic Perspectives, 9(3), 15-32

- (2007), The big Doubling: The Challenge of the New Global Labor Market, in: J. Edwards, M. Craine and A.L. Kallemberg, (eds.), "Ending Poverty in America: How to restore the American Dream", The New Press: New York.

Frobel, F., S. Heinrichs and O. KreYe (1980), The New International Division of Labour, Cambridge University Press: Cambridge.

Gasiorek, M., A. Smith and A.J. Venables (1994), "Modelling the effect of Central and Eastern European Trade on the European Economy”, European Economy, 1994(6), 519-538.

GeIsHeCKer, I. (2006), "Does outsourcing to Central and Eastern Europe really threaten manual workers' jobs in Germany?", World Economy, 29(5), 559-583.

Ginzburg, A. (1984), "Dependency and the Political Solution of Balance of Payments Crises: the Italian Case", Studi e Ricerche del Dipartimento di Economia Politica, 25, Università degli Studi di Modena.

- and A. Simonazzi (1995), Patterns of Production and Distributions in Europe: the Case of the Textile and Clothing Sector, in: R. Schiattarella, (ed.), "New Challenges for European and International Business", Litografia Ranieri: Roma.

Goldberg, P. K. and N. PavcniK (2007),'Distributional effects of globalization in developing countries", Journal of Economic Literature, 45(1), 39-82.

Graziani, G. (2001), International Subcontracting in the Textile and Clothing Industry, in: S.W. Arndt and H. Kierzkowski, (eds.), "Fragmentation: New Production Patterns in the World Economy", Oxford University Press: Oxford.

Greenaway, D., R. Hine and C. Milner (1995), "Vertical and horizontal intra-industry trade: a cross industry analysis for the United Kingdom", Economic Journal, 105(433), 1505-1518.

Grossman, G. and E. Rossi-Hansberg (2006), “Trading Tasks: A Simple Theory of Offshoring", American Economic Review, 98(5), 1978-1997. 
Hamilton C., L.A. Winters, G. Hughes and A. Smith (1992), "Opening up International Trade with Eastern Europe", Economic Policy, 7(14), 77-116.

Harrison, A. E. and G. Hanson (1999), "Who gains from trade reform? Some remaining puzzles", Journal of Development Economics, 59(1), 125-154.

Helg, R. and L. Tajoli (2005), "Pattern of international fragmentation of production and the relative demand for labor", North American Journal of Economics and Finance, 16(2), 233-254.

Hertveldt, B. and B. Michel (2012), "Offshoring and the Skill Structure of Labour Demand in Belgium", FPB Working Paper 7-12.

HsieH, C.T. and K.T. Woo (2005), "The impact of outsourcing to China on Hong Kong's labor market", American Economic Review, 95(5), 1673-1687.

Hummels D., Rapoport D. and Yi K. (1998), "Vertical Specialization and the Changing Nature of World Trade", FRBNY Economic Policy Review, June, 79-99.

Krugman, P. (1994), Peddling Prosperity : Economic Sense and Nonsense in the Age of Diminished Expectations, Norton: New York

— and R. Lawrence (1994), "Trade, jobs and wages", Scientific American, 270(4), 44-49.

Lawrence, R. and M. Slaughter (1993), "Trade and U.S. wages: great sucking sound or small hiccup?", Brookings Papers in Economic Activity: Microeconomics, 1993(2), 161-226.

LEAmer, E.E. (1995), A Trade Economist's View of US Wages and Globalisation, in: S.M. Collins, (ed.), "Imports, Exports and the American Workers", Brooking Institution Press: Washington.

LEWIS, M. (1995), "Clothing manufacturing and distribution in France", Textile Outlook International, 53(3), 32-74.

Lorentowicz, A., D. Marin and A. Raubold (2005), "Is human capital losing from outsourcing? Evidence for Austria and Poland", CEPR Discussion Paper No. 5344.

Melitz, M. J. (2003): “The Impact of Trade on Intra-Industry Reallocations and Aggregate Industry Productivity", Econometrica, 71(6), 1695-1725. 
Pellegrin, J. (1995), "Trade Adjustment in the Textile and Clothing sector: OPT between The European Union and The Czech Lands", ACE Conference on the Textile and Clothing Industry-Adjustment and Trade Performance, Lodz, March 4-5.

RicchetTi, M. (1993), "Il TPP: quali conseguenze sul sistema italiano del tessile/abbigliamento", Tecnica della Confezione, n. 174.

Roemer, J.E. (1977), "The Effects of Sphere of Influence and Economic Distance on the Commodity Composition of Trade in Manufactures", Review of Economics and Statistics, 59(3), 318-327.

SAChS, J. and H. Shatz (1994), "Trade and jobs in U.S. manufacturing", Brookings Papers in Economic Activity, 1994(1), 1-84.

SCHEFfER, M. (1994), "Internationalisation of Production by EC Textile and Clothing Manufacturers", Textile Outlook International, 52(1), 101-123.

Steele, P. (1995), "Textile and Garment Sourcing and the Single European Market", Textile Outlook International, 53(1), 114-131.

Smith, A. (1994), "Central and Eastern Europe Trade Performance in the European Union Market", IESG Conference, September.

Wang, Z. and L.A. Winters (1991), “The Trading Potential of Eastern Europe: Impact on Members of the EC", CEPR Discussion Paper no. 610.

Winters, L.A. (1992), "The Europe Agreements: with a Little Help from Our Friends", CEPR Occasional Papers, 11.

Wood, A. (1994), North-South Trade, Employment and Inequality: Changing Fortunes in a Skill-Driven World, Oxford University Press: Oxford. 


\section{Annex}

German tables

Table 1-A

\begin{tabular}{|c|c|c|c|c|c|c|c|}
\hline \multicolumn{8}{|c|}{ Percentage shares } \\
\hline & \multicolumn{7}{|c|}{1989} \\
\hline & Extra-EU & \multicolumn{6}{|c|}{ Areas } \\
\hline \multicolumn{8}{|l|}{ Sectors* } \\
\hline Text-appar & $54 \%$ & $8 \%$ & $14 \%$ & $78 \%$ & $0 \%$ & $0 \%$ & $100 \%$ \\
\hline Mec-Elect & $26 \%$ & $1 \%$ & $73 \%$ & $7 \%$ & $18 \%$ & $0 \%$ & $100 \%$ \\
\hline Transport & $1 \%$ & $27 \%$ & $14 \%$ & $39 \%$ & $19 \%$ & $0 \%$ & $100 \%$ \\
\hline Others & $19 \%$ & $2 \%$ & $11 \%$ & $73 \%$ & $15 \%$ & $0 \%$ & $100 \%$ \\
\hline \multirow[t]{3}{*}{ Total Manuf } & $100 \%$ & $4 \%$ & $36 \%$ & $49 \%$ & $10 \%$ & $0 \%$ & $100 \%$ \\
\hline & \multicolumn{7}{|c|}{1997} \\
\hline & Extra-EU & Africa & Asia** & $\mathrm{CEEC}^{* *}$ & $\begin{array}{l}\text { Areas } \\
\text { North Ame }\end{array}$ & South Ame** & Tot Areas \\
\hline \multicolumn{8}{|l|}{ Sectors $^{*}$} \\
\hline Text-appar & $48 \%$ & $7 \%$ & $5 \%$ & $87 \%$ & $0 \%$ & $0 \%$ & $100 \%$ \\
\hline Mec-Elect & $31 \%$ & $1 \%$ & $56 \%$ & $33 \%$ & $9 \%$ & $0 \%$ & $100 \%$ \\
\hline Transport & $7 \%$ & $0 \%$ & $1 \%$ & $14 \%$ & $85 \%$ & $0 \%$ & $100 \%$ \\
\hline Others & $14 \%$ & $1 \%$ & $11 \%$ & $72 \%$ & $17 \%$ & $0 \%$ & $100 \%$ \\
\hline Total Manuf & $100 \%$ & $4 \%$ & $24 \%$ & $59 \%$ & $13 \%$ & $0 \%$ & $100 \%$ \\
\hline
\end{tabular}

${ }^{*}$ ) Text-appar: 50-63; Mec-Elect: 84-85; Transport: 86-89; Total manuf: 28-99

${ }^{* *}$ Selected countries

Source: Comext

Table 2-A

\begin{tabular}{|c|c|c|c|c|c|c|c|c|}
\hline & \multicolumn{6}{|c|}{ nports+Exports, thousand of ECUs) } & & \\
\hline & \multicolumn{7}{|c|}{ Areas } & South Ame** \\
\hline \multicolumn{9}{|l|}{ Sectors $^{*}$} \\
\hline Text-appar & \multicolumn{2}{|c|}{$17 \%$} & $8 \%$ & & $4 \%$ & $276 \%$ & $0 \%$ & $0 \%$ \\
\hline Mec-Elect & \multicolumn{2}{|c|}{$2 \%$} & $0 \%$ & & $9 \%$ & $5 \%$ & $2 \%$ & $0 \%$ \\
\hline Transport & \multicolumn{2}{|c|}{$0 \%$} & $0 \%$ & & $0 \%$ & $2 \%$ & $0 \%$ & $0 \%$ \\
\hline Total 3 & \multicolumn{2}{|c|}{$4 \%$} & $2 \%$ & & $7 \%$ & $41 \%$ & $1 \%$ & $0 \%$ \\
\hline \multirow[t]{4}{*}{ Total Manuf } & \multicolumn{2}{|c|}{$2 \%$} & $1 \%$ & & $4 \%$ & $25 \%$ & $1 \%$ & $0 \%$ \\
\hline & \multicolumn{8}{|c|}{1997} \\
\hline & \multicolumn{8}{|c|}{ Areas } \\
\hline & Extra-EU & Africa & & Asia** & & & North Ame & South Ame** \\
\hline \multicolumn{9}{|l|}{ Sectors ${ }^{*}$} \\
\hline Text-appar & 34 & & $26 \%$ & & $5 \%$ & $172 \%$ & $1 \%$ & $3 \%$ \\
\hline Mec-Elect & & & $1 \%$ & & $9 \%$ & $9 \%$ & $2 \%$ & $0 \%$ \\
\hline Transport & & & $0 \%$ & & $0 \%$ & $2 \%$ & $16 \%$ & $0 \%$ \\
\hline Total 3 & & & $6 \%$ & & $7 \%$ & $24 \%$ & $5 \%$ & $0 \%$ \\
\hline Total Manuf & & & $4 \%$ & & $5 \%$ & $15 \%$ & $3 \%$ & $0 \%$ \\
\hline
\end{tabular}

$\left.{ }^{*}{ }^{*}\right)$ Text-appar: 50-63; Mec-Elect: 84-85; Transport: 86-89; Total manuf: 28-99

$\left.{ }^{* *}\right)$ Selected countries

Source: Comext 
Table 3-A

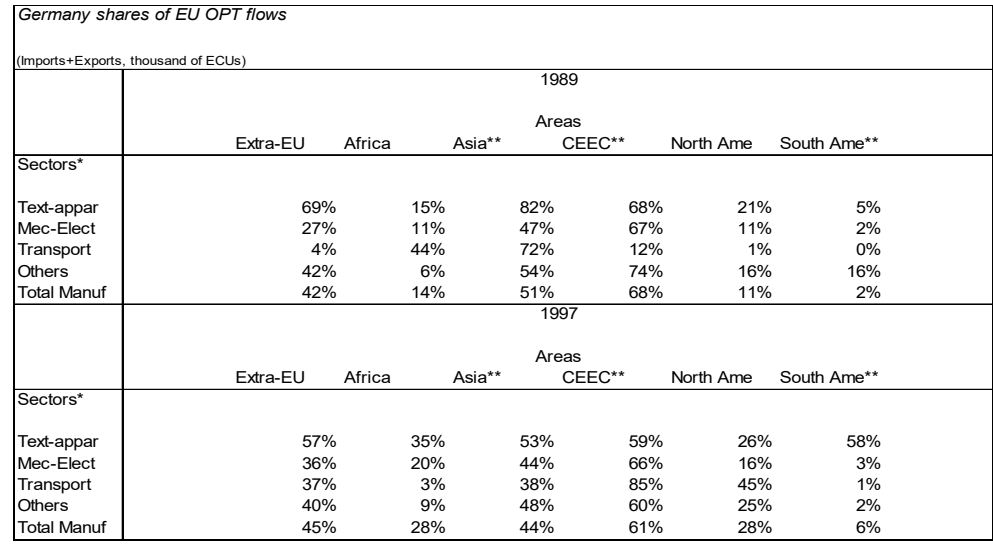

(*) Text-appar: 50-63; Mec-Elect: 84-85; Transport: 86-89; Total manuf: 28-99

$\left({ }^{* *}\right)$ Selected countries

Source: Comext

Italian tables

Table 4-A

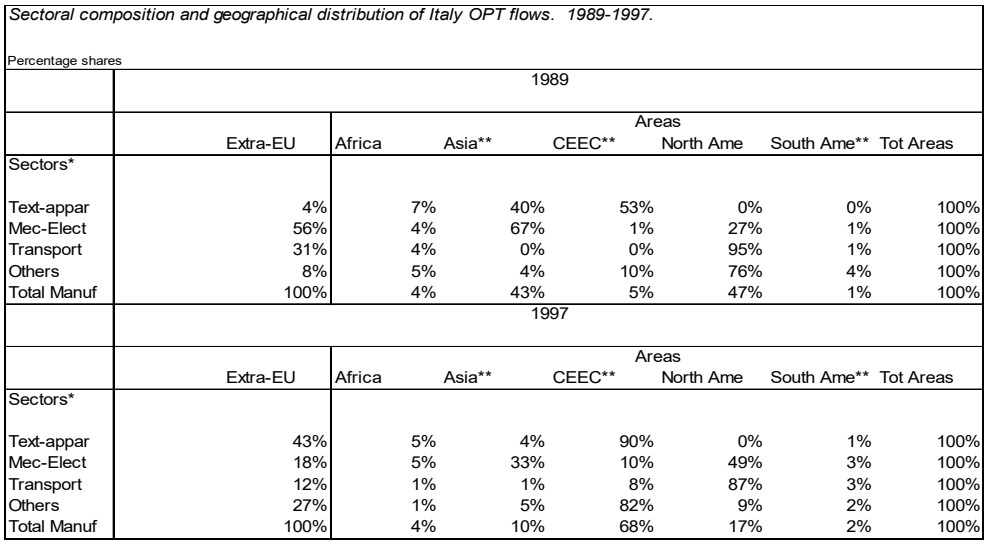

$\left.{ }^{*}\right)$ Text-appar: 50-63; Mec-Elect: 84-85; Transport: 86-89; Total manuf: 28-99

$\left({ }^{* *}\right)$ Selected countries

Source: Comext 
Table 5-A

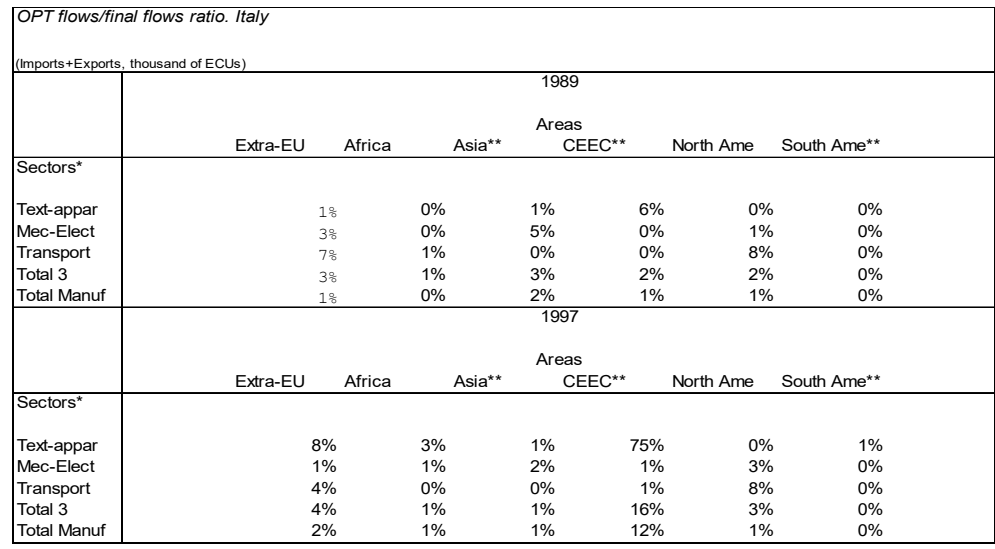

$\left.{ }^{*}\right)$ Text-appar: 50-63; Mec-Elect: 84-85; Transport: 86-89; Total manuf: 28-99

$\left.{ }^{* *}\right)$ Selected countries

Table 6-A

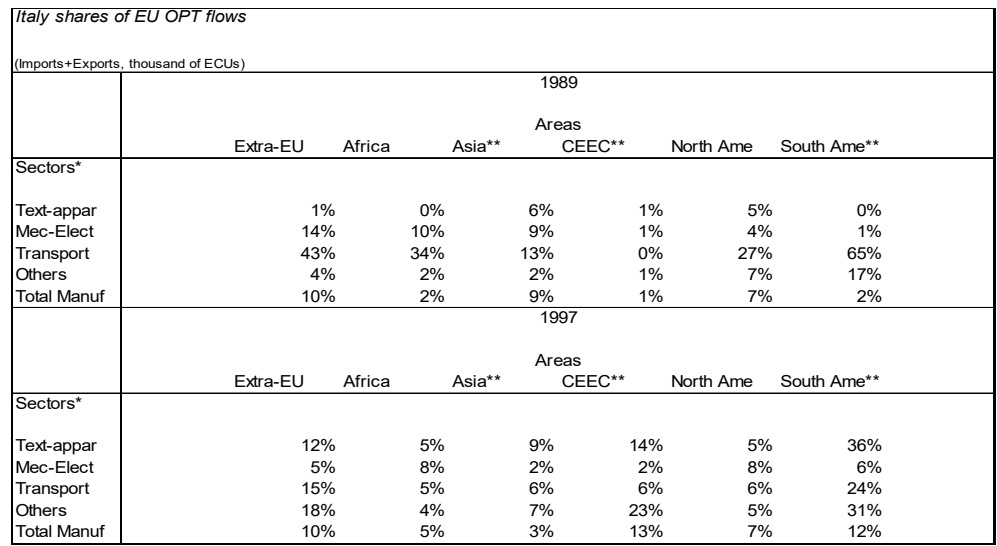

(*) Text-appar: 50-63; Mec-Elect: 84-85; Transport: 86-89; Total manuf: 28-99

$\left.{ }^{* *}\right)$ Selected countries 
French tables

Table 7-A

\begin{tabular}{|c|c|c|c|c|c|c|c|c|}
\hline \multicolumn{9}{|c|}{ Sectoral composition and geographical distribution of France OPT flows. 1989-1997. } \\
\hline & \multicolumn{8}{|c|}{1989} \\
\hline & Extra-EU & \multicolumn{7}{|c|}{ Areas } \\
\hline \multicolumn{9}{|l|}{ Sectors $^{*}$} \\
\hline Text-appar & $28 \%$ & $73 \%$ & $1 \%$ & & $26 \%$ & $0^{\circ}$ & $0 \%$ & $100 \%$ \\
\hline Mec-Elect & $37 \%$ & $12 \%$ & $27 \%$ & & $2 \%$ & $35^{\circ}$ & $24 \%$ & $100 \%$ \\
\hline Transport & $9 \%$ & $1 \%$ & $0 \%$ & & $1 \%$ & $98^{\circ}$ & $0 \%$ & $100 \%$ \\
\hline Others & $26 \%$ & $42 \%$ & $7 \%$ & & $16 \%$ & $34^{\circ}$ & $1 \%$ & $100 \%$ \\
\hline \multirow[t]{4}{*}{ Total Manuf } & $100 \%$ & $36 \%$ & $12 \%$ & & $12 \%$ & $29^{\circ}$ & $10 \%$ & $100 \%$ \\
\hline & \multicolumn{8}{|c|}{1997} \\
\hline & \multirow[b]{2}{*}{ Extra-EU } & \multirow{2}{*}{\multicolumn{7}{|c|}{$\begin{array}{ll} & \text { Areas } \\
\text { CEEC }^{* *} & \text { North Ame }\end{array}$}} \\
\hline & & & & & & & & \\
\hline \multicolumn{9}{|l|}{ Sectors $^{*}$} \\
\hline Text-appar & $20 \%$ & $39 \%$ & $1 \%$ & & $59 \%$ & $0^{\circ}$ & $0 \%$ & $100 \%$ \\
\hline Mec-Elect & $49 \%$ & $7 \%$ & $62 \%$ & & $6 \%$ & $18^{\circ}$ & $7 \%$ & $100 \%$ \\
\hline Transport & $14 \%$ & $3 \%$ & $1 \%$ & & $1 \%$ & $93^{\circ}$ & $2 \%$ & $100 \%$ \\
\hline Others & $17 \%$ & $33 \%$ & $9 \%$ & & $12 \%$ & $46^{\circ}$ & $0 \%$ & $100 \%$ \\
\hline Total Manuf & $100 \%$ & $17 \%$ & $37 \%$ & & $17 \%$ & $25^{\circ}$ & $4 \%$ & $100 \%$ \\
\hline
\end{tabular}

${ }^{*}$ ) Text-appar: 50-63; Mec-Elect: 84-85; Transport: 86-89; Total manuf: 28-99

$\left(^{* *}\right)$ Selected countries

Source: Comext

Table 8-A

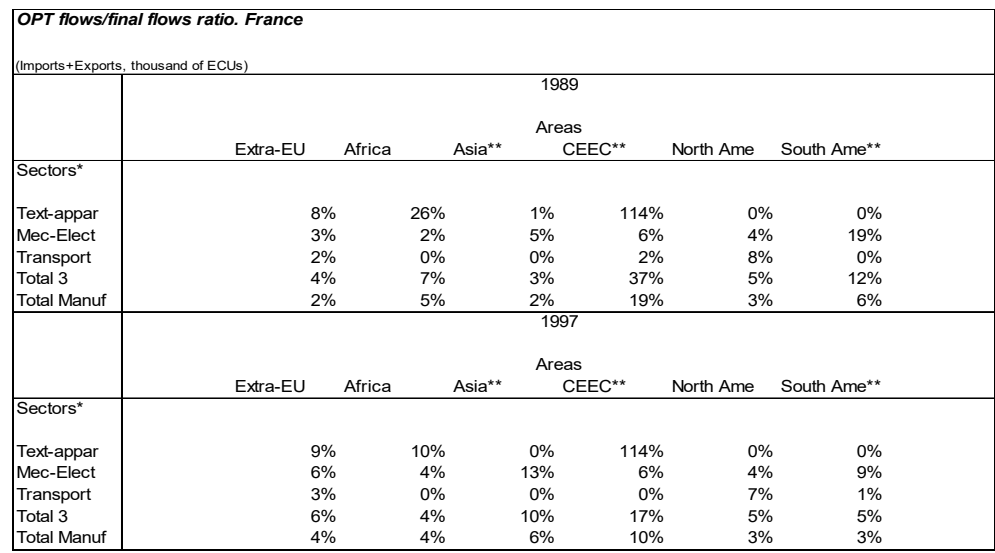

(*) Text-appar: 50-63; Mec-Elect: 84-85; Transport: 86-89; Total manuf: 28-99 $\left({ }^{* *}\right)$ Selected countries

Source: Comext 
Table 9-A

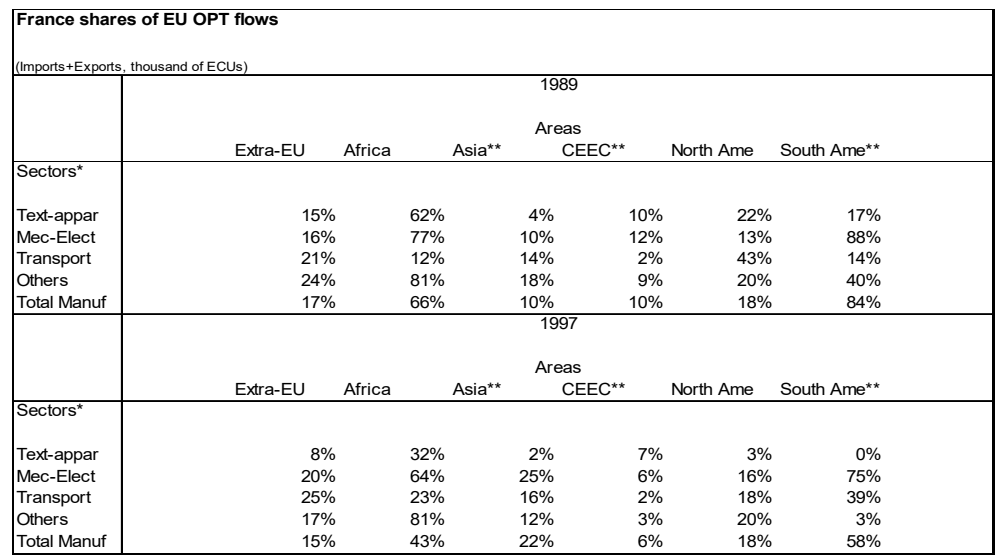

(*) Text-appar: 50-63; Mec-Elect: 84-85; Transport: 86-89; Total manuf: 28-99 $\left({ }^{\star \star}\right)$ Selected countries

Source: Comext

Dutch tables

Table 10-A

\begin{tabular}{|c|c|c|c|c|c|c|c|c|}
\hline \multicolumn{9}{|c|}{ Percentage shares } \\
\hline & \multicolumn{8}{|c|}{1989} \\
\hline & Extra-EU & \multicolumn{7}{|c|}{ Areas } \\
\hline \multicolumn{9}{|l|}{ Sectors ${ }^{*}$} \\
\hline Text-appar & $18 \%$ & $35 \%$ & $3 \%$ & & & $0 \%$ & $0 \%$ & $100 \%$ \\
\hline Mec-Elect & $74 \%$ & $0 \%$ & $20 \%$ & & & $78 \%$ & $1 \%$ & $100 \%$ \\
\hline Transport & $2 \%$ & $0 \%$ & $0 \%$ & & & $99 \%$ & $0 \%$ & $100 \%$ \\
\hline Others & $6 \%$ & $3 \%$ & $2 \%$ & & & $82 \%$ & $3 \%$ & $100 \%$ \\
\hline \multirow[t]{4}{*}{ Total Manuf } & $100 \%$ & $4 \%$ & $17 \%$ & & & $70 \%$ & $1 \%$ & $100 \%$ \\
\hline & \multicolumn{8}{|c|}{1997} \\
\hline & \multirow[b]{2}{*}{ Extra-EU } & \multicolumn{7}{|c|}{ Areas } \\
\hline & & Africa & Asia*** & $\mathrm{CEEC}^{\star *}$ & & Ame & South $A m e^{* *}$ & Tot Areas \\
\hline \multicolumn{9}{|l|}{ Sectors ${ }^{\star}$} \\
\hline Text-appar & $30 \%$ & $22 \%$ & $2 \%$ & & & $2 \%$ & $0 \%$ & $100 \%$ \\
\hline Mec-Elect & $61 \%$ & $1 \%$ & $66 \%$ & & & $29 \%$ & $1 \%$ & $100 \%$ \\
\hline Transport & $2 \%$ & $4 \%$ & $5 \%$ & & & $69 \%$ & $14 \%$ & $100 \%$ \\
\hline Others & $7 \%$ & $5 \%$ & $11 \%$ & & & $48 \%$ & $10 \%$ & $100 \%$ \\
\hline Total Manuf & $100 \%$ & $8 \%$ & $41 \%$ & & & $23 \%$ & $2 \%$ & $100 \%$ \\
\hline
\end{tabular}

${ }^{*}$ ) Text-appar: 50-63; Mec-Elect: 84-85; Transport: 86-89; Total manuf: 28-99

$\left.{ }^{* *}\right)$ Selected countries

Source: Comext 
Table 11-A

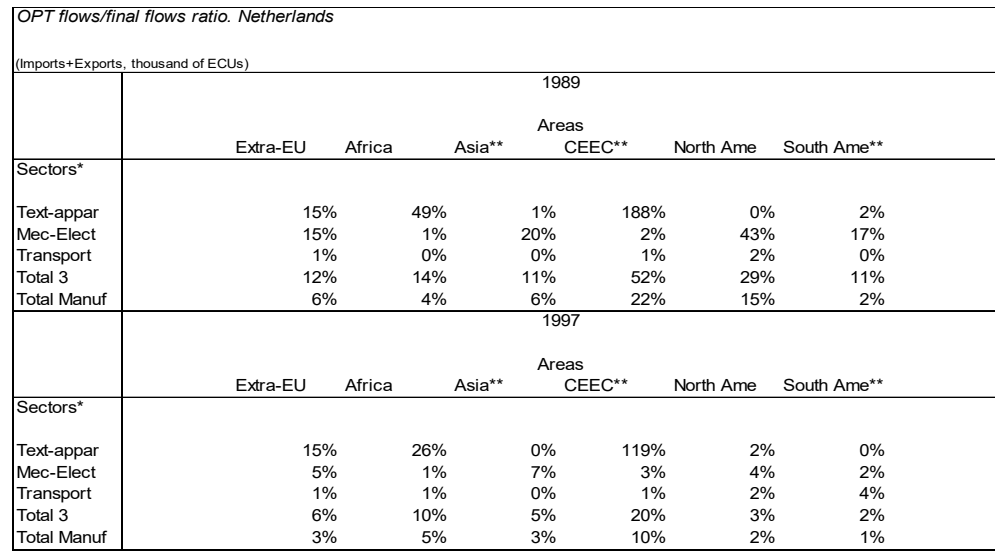

${ }^{*}$ ) Text-appar: 50-63; Mec-Elect: 84-85; Transport: 86-89; Total manuf: 28-99 $\left.{ }^{\star *}\right)$ Selected countries

Source: Comext

Table 12-A

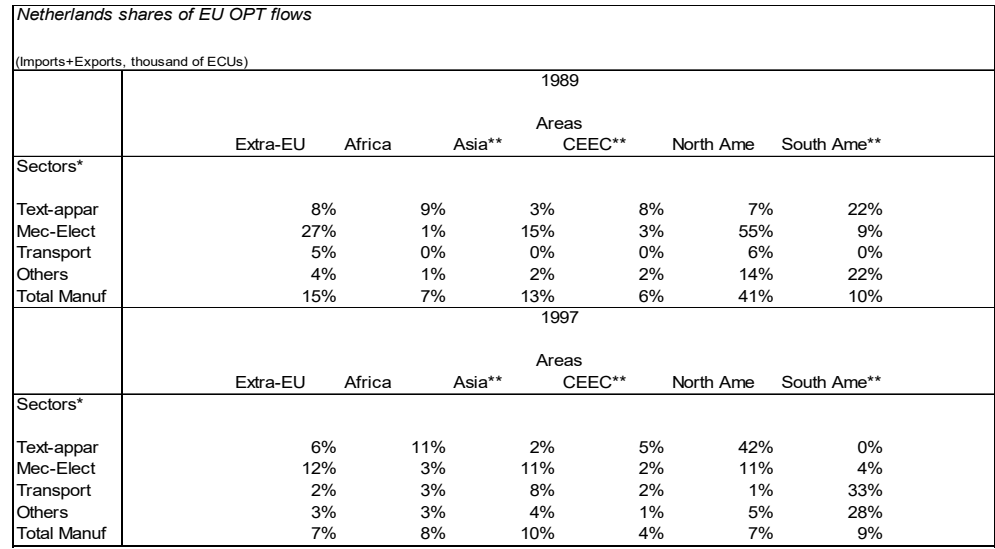

(*) Text-appar: 50-63; Mec-Elect: 84-85; Transport: 86-89; Total manuf: 28-99

$\left.{ }^{* *}\right)$ Selected countries

Source: Comex 
Abstract: This paper evaluates the differential impact of Outward Processing Traffic (OPT) flows with respect to the final trade flows on the labour markets of EU countries in the 1990s. In particular, two EU countries are investigated, Germany and Italy, because of their relevance on total EU-CEECs OPT flows and because they embody two different models of outsourcing towards CEECs. The factor content of trade (FCT) analysis conducted at both levels of inter-industry trade and intra-industry trade signals a more relevant impact of OPT flows than final flows. In particular, results suggest that the labour market effects of intra-industry trade flows deriving from the vertical disintegration of production add significantly to the estimated factor market impact of trade.

Keywords: intra-industry trade; EU-CEECs trade; vertical disintegration; quality differentiation; labour market effects of international trade.

Giuseppe Celi

Dipartimento di Economia, Università di Foggia — Italia 